\title{
Polyphasic Taxonomy of Rhizobia: Emendation of the Genus Sinorhizobium and Description of Sinorhizobium meliloti comb. nov., Sinorhizobium saheli sp. nov., and Sinorhizobium teranga sp. nov.
}

\author{
PHILIPPE DE LAJUDIE, ${ }^{1}$ ANNE WILLEMS, ${ }^{2,3}$ BRUNO POT, ${ }^{2}$ DIRK DEWETTINCK, ${ }^{2}$ \\ GLORIA MAESTROJUAN,${ }^{2}$ MARC NEYRA,${ }^{1}$ MATTHEW DAVID COLLINS, ${ }^{3}$ \\ BERNARD DREYFUS, ${ }^{1}$ KAREL KERSTERS, ${ }^{2}$ AND MONIQUE GILLIS ${ }^{2 *}$ \\ Laboratoire de Microbiologie des Sols, ORSTOM BP 1386, Dakar, Senegal, West Africa ${ }^{1}$; Laboratorium voor \\ Microbiologie, Universiteit Gent, B-9000 Ghent, Belgium ${ }^{2}$; and Microbiology Department, Reading \\ Laboratory, Agricultural and Food Research Council Institute of Food Research, \\ Earley Gate, Reading, RG6 2EF, United Kingdom ${ }^{3}$
}

\begin{abstract}
A total of 80 bacterial strains isolated from different Sesbania and Acacia species growing in various sites in Senegal (West Africa) were compared with 35 reference strains of Rhizobium, Bradyrhizobium, Azorhizobium, and Agrobacterium species and with 33 representative strains of the different groups of Brazilian isolates described on the basis of the results of a numerical analysis of the whole-cell protein patterns obtained by sodium dodecyl sulfate-polyacrylamide gel electrophoresis (SDS-PAGE). Fifty-two strains could be placed in three protein electrophoretic clusters, two of which were different from the clusters containing various reference or representative strains, while 30 other strains could not be placed in any group. The strains belonging to the three clusters were studied by determining their nodulation host ranges and their morphological, physiological, and auxanographic characteristics. Representative strains of the three clusters were also genotypically characterized by determining their DNA base compositions, by performing DNA-DNA and DNA-rRNA hybridization experiments, and by determining their $16 S$ rRNA gene sequences. Our results showed that two of the clusters identified on the basis of SDS-PAGE data are genotypically and phenotypically distinct groups that belong on the Rhizobium meliloti-Rhizobium fredii rRNA branch. The third cluster is localized on the Rhizobium loti rRNA branch in the vicinity of Rhizobium huakuii and contains strains isolated in Africa, in Brazil, and in New Zealand from different leguminous species. On the basis of the results of the present study, we propose to emend the genus Sinorhizobium and to reclassify $R$. meliloti as Sinorhizobium meliloti comb. nov. In addition, two new species, Sinorhizobium saheli and Sinorhizobium teranga, are proposed for isolates from Senegal.
\end{abstract}

Classification of the legume root-nodulating bacteria has undergone major revisions and improvements in recent years (20). In particular, polyphasic taxonomy, which involves techniques that have various powers of discrimination, has been used, and the use of this method has resulted in a greater understanding of the complex intra- and intergeneric relationships of Rhizobium and Bradyrhizobium species (for a review see reference 17). In addition to the genera Rhizobium and Bradyrhizobium, a third genus, Azorhizobium, with the single species Azorhizobium caulinodans, was created by Dreyfus et al. (14) for stem-nodulating strains isolated from Sesbania rostrata; a second genotypic group in this genus was subsequently described $(35,36)$.

Within the genus Rhizobium the following three species were described by Jordan in 1984 (20): Rhizobium meliloti, Rhizobium loti, and type species Rhizobium leguminosarum, containing three biovars. Since then five other species have been created: Rhizobium galegae for isolates obtained from Galega officinalis and Galega orientalis (26), Rhizobium huakuii for strains obtained from Astragalus sinicus (4), Rhizobium tropici for the former $R$. leguminosarum biovar phaseoli type II strains (30), Rhizobium etli for the $R$. leguminosarum biovar

* Corresponding author. Mailing address: Laboratorium voor Microbiologie, Universiteit Gent, K.-L. Ledeganckstraat, 35, B-9000 Ghent, Belgium. Phone: 329264 5117. Fax: 329264 5346. Electronic mail address: Moniek.Gillis@rug.ac.be. phaseoli type I strains (39), and Rhizobium fredii for the fast-growing soybean-nodulating strains (38). $R$. fredii has been assigned to the genus Sinorhizobium (5), and a second species, Sinorhizobium xinjiangensis, has been proposed for fast-growing soybean-nodulating isolates obtained from the Xinjiang region in the People's Republic of China. The phylogenetic distinctness of the genus Sinorhizobium and the species status of Sinorhizobium xinjiangensis have been questioned on the basis of the results of rRNA studies $(18,19)$. All Rhizobium species belong to the alpha subclass of the Proteobacteria, where they constitute a single rRNA cluster together with Agrobacterium, Brucella, and Rochalimaea spp. (14, 19, 44, 46, 47). Within this rRNA cluster different groups can be differentiated; one of these groups is the Agrobacterium-Rhizobium group. Within this group $R$. leguminosarum, $R$. tropici, $R$. etli, and Agrobacterium biovar 2 constitute one subgroup (39, 44, 47). $R$. galegae constitutes a second subgroup together with Agrobacterium biovar 1, Agrobacterium vitis, and Agrobacterium rubi. $R$. meliloti and $R$. fredii are the members of a third subgroup, while $R$. lot $i$ and $R$. huakuii form a fourth sublineage $(44,46,48)$. In the near future revision of the classification and nomenclature of these genera will be unavoidable. Recently, Sawada et al. (37) proposed that Agrobacterium biovars 1 and 2 should have species status; they proposed that the name Agrobacterium tumefaciens should be rejected and provided revised descriptions for Agrobacterium radiobacter (for the biovar 1 strains) and Agrobacterium rhizogenes (for the biovar 2 
strains). In this proposal Agrobacterium radiobacter became the type species of the genus Agrobacterium. In a request for a Judicial Opinion concerning the type species of the genus Agrobacterium, Bouzar (2) emphasized that Sawada et al. (37) did not take into account key judicial elements in Agrobacterium nomenclature, and Sawada et al. agreed with this request (2). As long as this request has not been considered, we shall use the Agrobacterium nomenclature used by Kersters and De Ley (21).

Most taxonomic work performed to date has been focused on strains that nodulate agriculturally important legumes. Other tropical rhizobia have been studied only sparsely, especially tropical rhizobia isolated from leguminous trees. Previous studies revealed that Acacia species are nodulated by Rhizobium and/or Bradyrhizobium strains (15), while Sesbania species are nodulated by Rhizobium and/or Azorhizobium strains (14). Isolates obtained from 36 Sesbania and Acacia species were grouped into three phenotypic clusters by Dreyfus et al. (14). By performing a numerical phenotypic analysis, Zhang et al. (49) showed that rhizobia isolated from root nodules of Acacia senegal and Prosopis chiliensis in Sudan are very diverse and can be placed in at least eight clusters that are distinct from previously described Rhizobium species. Moreira et al. (31) compared 180 slowly growing and fast-growing isolates obtained from nodules of tropical leguminous species in the Amazonian region and the Atlantic forests of Brazil with representatives of the different Bradyrhizobium species, Rhizobium species (except $R$. etli and $R$. huakuii), and Azorhizobium species by performing a sodium dodecyl sulfate (SDS)-polyacrylamide gel electrophoresis (PAGE) analysis of their total proteins. Within the fast-growing isolates Moreira et al. identified several clusters which differed from the previously described species.

In this paper we describe the results of a polyphasic study (which included SDS-PAGE of cellular proteins, auxanographic tests, host specificity tests, DNA-DNA hybridization and DNA-rRNA hybridization experiments, and 16S rRNA gene sequencing) of 52 strains isolated from Acacia spp. and Sesbania spp. in Senegal, West Africa. Reference strains of Azorhizobium caulinodans, Bradyrhizobium japonicum, and different Rhizobium species were also included, together with representative strains of the different clusters of Brazilian rhizobia (31). On the basis of our results we propose that $R$. meliloti be reclassified in the genus Sinorhizobium as Sinorhizobium meliloti comb. nov. In addition, two new species, Sinorhizobium saheli and Sinorhizobium teranga, are created for two taxa comprising the new Senegalese isolates.

\section{MATERIALS AND METHODS}

Bacterial strains. Rhizobial strains were isolated from naturally occurring Sesbania root nodules or from root nodules harvested from young seedlings of different Acacia species grown in tubes in the presence of a soil suspension as follows. Soil samples collected at depths of 5 to $20 \mathrm{~cm}$ in various regions of Senegal in the neighborhood of a particular Acacia sp. were screened for the presence of rhizobial strains by inoculating 5to 8-day-old Acacia seedlings of the same species grown in Jensen slant agar tubes containing $1 \mathrm{ml}$ of a soil suspension $(10 \%$, wt/vol $)$ that had been magnetically stirred for $30 \mathrm{~min}$. Root nodules appeared after 1 to 3 weeks, and 2-week-old nodules were collected. The nodules were washed and immersed in $0.1 \% \mathrm{HgCl}_{2}$ for $5 \mathrm{~min}$; after this the nodules were manipulated aseptically. Each nodule was rinsed eight times in sterile water and crushed in 1 drop of sterile water. The resulting suspension was streaked onto yeast mannitol agar
(YMA) (see below), and isolated colonies appeared after incubation for 2 or 3 days at $33^{\circ} \mathrm{C}$. Pure cultures were obtained after single colonies were streaked two or three times.

All of the strains which we used are shown in Table 1. These strains were checked for purity by repeatedly streaking them on YMA and by examining living and Gram-stained cells with a microscope. When two stable colony morphology variants were obtained, both were included in the SDS-PAGE analysis, and these variants were designated $t 1$ and $t 2$. The identities of the nodulating strains were checked by performing plant infection tests with the original host plants.

Type or representative strains of most Rhizobium species, $B$. japonicum, Bradyrhizobium elkanii, Azorhizobium caulinodans, and the various clusters of Brazilian rhizobia described by Moreira et al. (31) were included in this polyphasic study. $R$. huakuii was included only in the auxanographic tests because we obtained the type strain only recently. $R$. etli and $S$. xinjiangensis were not included.

Growth and culture conditions. All Rhizobium and Bradyrhizobium strains were maintained on YMA, which contained (per liter) $10 \mathrm{~g}$ of mannitol, $0.5 \mathrm{~g}$ of sodium glutamate, $0.5 \mathrm{~g}$ of $\mathrm{K}_{2} \mathrm{HPO}_{4}, 0.2 \mathrm{~g}$ of $\mathrm{MgSO}_{4} \cdot 7 \mathrm{H}_{2} \mathrm{O}, 0.05 \mathrm{~g}$ of $\mathrm{NaCl}, 0.04 \mathrm{~g}$ of $\mathrm{CaCl}_{2}, 0.004 \mathrm{~g}$ of $\mathrm{FeCl}_{3}, 1 \mathrm{~g}$ of yeast extract (Difco), and $20 \mathrm{~g}$ of agar; the $\mathrm{pH}$ of this medium was 6.8. Azorhizobium and Agrobacterium strains were maintained on yeast extract-peptone-glucose medium, which contained (per liter of $0.01 \mathrm{M}$ phosphate buffer [pH 7.2]) $5 \mathrm{~g}$ of peptone (Oxoid), $1 \mathrm{~g}$ of yeast extract (Oxoid), $5 \mathrm{~g}$ of beef extract (Oxoid), $5 \mathrm{~g}$ of sucrose, and $0.592 \mathrm{~g}$ of $\mathrm{MgSO}_{4} \cdot 7 \mathrm{H}_{2} \mathrm{O}$. All strains were stored at $-80^{\circ} \mathrm{C}$ on the same medium on which they were maintained, except that the medium contained $20 \%$ (vol/vol) glycerol. Mycoplana, Ochrobactrum, and Phyllobacterium strains were maintained on nutrient agar, which contained (per liter) $1 \mathrm{~g}$ of beef extract (Oxoid), $2 \mathrm{~g}$ of yeast extract (Oxoid), $5 \mathrm{~g}$ of peptone (Oxoid), $5 \mathrm{~g}$ of $\mathrm{NaCl}$, and $20 \mathrm{~g}$ of agar; the $\mathrm{pH}$ of this medium was 7.4.

Morphological and physiological tests. Cell dimensions and morphology were determined by phase-contrast microscopy. Cells of two or three representative strains of each group were negatively stained with phosphotungstic acid, and the type of flagellation was determined by transmission electron microscopy (25).

Four to eight representatives of each group were used to determine the maximum growth temperature of the taxon by inoculating them onto YMA plates and incubating the resulting cultures at various temperatures.

PAGE of total bacterial proteins. Most strains were grown at $28^{\circ} \mathrm{C}$ for $48 \mathrm{~h}$ (the exceptions were the bradyrhizobia, which were grown for $72 \mathrm{~h}$ ) in Roux flasks on TY medium, which contained (per liter) $5 \mathrm{~g}$ of tryptone (Oxoid), $0.75 \mathrm{~g}$ of yeast extract (Oxoid), $0.454 \mathrm{~g}$ of $\mathrm{KH}_{2} \mathrm{PO}_{4}, 2.388 \mathrm{~g}$ of $\mathrm{Na}_{2} \mathrm{HPO}_{4}$. $12 \mathrm{H}_{2} \mathrm{O}, 1 \mathrm{~g}$ of $\mathrm{CaCl}_{2}$, and $20 \mathrm{~g}$ of agar (Lab M) (pH 6.8 to 7). Whole-cell protein extracts were prepared, and SDS-PAGE was performed by using the procedure of Laemmli (24) with slight modifications, as described previously (23). The normalized densitometric traces of the protein electrophoretic patterns were grouped by performing a numerical analysis, using the GelCompar 2.2 software package (41). The level of similarity between each pair of traces was expressed by the Pearson product moment correlation coefficient $(r)$, which for convenience was converted to a percentage $(33,34)$.

Plant infection tests. Seeds were scarified and surface sterilized with concentrated sulfuric acid. The lengths of time that the seeds of the different plant species were treated with $\mathrm{H}_{2} \mathrm{SO}_{4}$ were as follows: Acacia senegal, $14 \mathrm{~min} ;$ Acacia albida, $30 \mathrm{~min}$; Acacia seyal, $30 \mathrm{~min}$; Acacia raddiana, $150 \mathrm{~min}$; Sesbania rostrata, 30 to $60 \mathrm{~min}$; Sesbania pubescens, $60 \mathrm{~min}$; 
TABLE 1. Strains used in this investigation

\begin{tabular}{|c|c|c|c|c|c|}
\hline Strain $^{a}$ & LMG no. & Host plant or source ${ }^{b}$ & Geographical origin $^{h}$ & Reference $^{b}$ & PAGE group ${ }^{c}$ \\
\hline \multicolumn{6}{|c|}{ New isolates } \\
\hline \multicolumn{6}{|c|}{$\begin{array}{c}\text { Sinorhizobium teranga } \\
\quad(\text { cluster } \mathrm{T})\end{array}$} \\
\hline ORS 22 & 6463 & Sesbania rostrata & Senegal & 15 & \\
\hline ORS 51 & 6464,7843 & Sesbania rostrata & Senegal & 15 & \\
\hline ORS 15 & 7833 & Sesbania sp. & Senegal & This study & \\
\hline ORS $1009^{\mathrm{T}}$ & $7834^{\mathrm{T}}$ & Acacia laeta & Senegal & 1 & \\
\hline ORS 19 & $7841 \mathrm{t} 1$ & Sesbania cannabina & Senegal & 32 & \\
\hline ORS 20 & $7841 \mathrm{t} 2$ & Nonmucous derivative of ORS 19 & & This study & \\
\hline ORS 1013 & 7844 & Acacia senegal & Senegal & This study & \\
\hline ORS 1007 & 7847 & Acacia laeta & Senegal & This study & \\
\hline ORS 1016 & $7851 \mathrm{t} 1$ & Acacia laeta & Senegal & This study & \\
\hline ORS 1079 & $7851 \mathrm{t} 2$ & Nonmucous derivative of ORS 1016 & & This study & \\
\hline ORS 929 & $8313 \mathrm{t} 1$ & Acacia sp. & Senegal & 14 & \\
\hline ORS 52 & 11859 & Sesbania rostrata & Senegal & 15 & \\
\hline ORS 53 & 11860 & Sesbania rostrata & Senegal & 15 & \\
\hline ORS 604 & 11865 & Sesbania aculeata & Senegal & 32 & \\
\hline ORS 613 & 11866 & Sesbania sesban & Senegal & 32 & \\
\hline ORS 8 & 11870 & Sesbania rostrata & Senegal & This study & \\
\hline ORS 1045 & 11901 & Acacia raddiana & Senegal & This study & \\
\hline ORS 1047 & 11903 & Acacia horrida & Senegal & This study & \\
\hline ORS 1057 & 11911 & Acacia mollissima & Senegal & This study & \\
\hline ORS 1058 & 11912 & Acacia mollissima & Senegal & This study & \\
\hline ORS 1071 & 11924 & Acacia senegal & Senegal & This study & \\
\hline ORS 1072 & 11925 & Acacia senegal & Senegal & This study & \\
\hline ORS 1073 & 11926 & Acacia senegal & Senegal & This study & \\
\hline \multicolumn{6}{|c|}{$\begin{array}{l}\text { Sinorhizobium saheli } \\
\text { (cluster S) }\end{array}$} \\
\hline ORS $609^{\mathrm{Td}}$ & $7837^{\mathrm{T}}$ & Sesbania cannabina & Senegal & 32 & \\
\hline ORS $609 \mathrm{t} 1$ & $8309 \mathrm{t} 1$ & Sesbania cannabina & Senegal & 32 & \\
\hline ORS $609 \mathrm{t} 2$ & $8309+2$ & Sesbania cannabina & Senegal & 32 & \\
\hline ORS 611 & 7842,8310 & Sesbania grandiflora & Senegal & 32 & \\
\hline ORS 10 & 11858 & Sesbania rostrata & Senegal & 32 & \\
\hline ORS 600 & 11864 & Sesbania pachycarpa & Senegal & 32 & \\
\hline \multicolumn{6}{|l|}{ Cluster U } \\
\hline NZP 2037 & 6123 & Lotus divaricatus & New Zealand & & 2 \\
\hline NZP 2014 & 6124 & Lotus corniculatus & & & \\
\hline ORS 1001 & 7836 & Acacia senegal & Senegal & 1 & \\
\hline ORS 1015 & 7839 & Acacia senegal & Senegal & 1 & \\
\hline ORS 1005 & $7845 \mathrm{t} 1$ & Acacia sp. & Senegal & This study & \\
\hline ORS 1004 & 7848 & Acacia senegal & Senegal & 1 & \\
\hline ORS $1014 \mathrm{t} 1$ & $7849 \mathrm{t} 1$ & Acacia senegal & Senegal & This study & \\
\hline ORS $1014 \mathrm{t} 2$ & $7849+2$ & Acacia senegal & Senegal & This study & \\
\hline ORS 1010 & 7853 & Acacia senegal & Senegal & This study & \\
\hline ORS 1002 & 7854 & Acacia senegal & Senegal & 1 & \\
\hline ORS 13 & 7921 & Acacia sp. & Senegal & This study & \\
\hline ORS 1088 & 11880 & Acacia seyal & Senegal & This study & \\
\hline ORS 1018 & 11881 & Acacia senegal & Senegal & This study & \\
\hline ORS 1020 & 11883 & Acacia senegal & Senegal & This study & \\
\hline ORS 1024 & 11884 & Acacia senegal & Senegal & This study & \\
\hline ORS 1029 & 11889 & Acacia senegal & Senegal & This study & \\
\hline ORS 1030 & 11890 & Acacia senegal & Senegal & This study & \\
\hline ORS 1031 & 11891 & Acacia senegal & Senegal & This study & \\
\hline ORS 1032 & 11892 & Acacia senegal & Senegal & This study & \\
\hline ORS 1035 & 11893 & Acacia senegal & Senegal & This study & \\
\hline ORS 1036 & 11894 & Acacia senegal & Senegal & This study & \\
\hline ORS 1037 & 11895 & Acacia senegal & Senegal & This study & \\
\hline ORS 1038 & 11896 & Acacia senegal & Senegal & This study & \\
\hline ORS 1040 & 11898 & Acacia senegal & Senegal & This study & \\
\hline ORS 1093 & & Acacia senegal & Senegal & This study & \\
\hline BR3804 & 9970 & Chamaecrista ensiformis & Brazil & 31 & 2 \\
\hline INPA $12 \mathrm{~A}$ & 10031 & Leucaena leucocephala & Brazil & 31 & 2 \\
\hline INPA 78B & 10056 & Leucaena diversifolia & Brazil & 31 & 2 \\
\hline INPA $118 \mathrm{~A}$ & 10059 & Leucaena pulvurulenta & Brazil & 31 & 2 \\
\hline INPA $129 \mathrm{~A}$ & 10061 & Leucaena pulvurulenta & Brazil & 31 & 2 \\
\hline INPA 338A & 10093 & Leucaena diversifolia & Brazil & 31 & 2 \\
\hline
\end{tabular}


TABLE 1-Continued

\begin{tabular}{|c|c|c|c|c|c|}
\hline Strain $^{a}$ & LMG no. & Host plant or source ${ }^{b}$ & Geographical origin $^{b}$ & Reference $^{b}$ & PAGE group $c$ \\
\hline ORS 1096 & 12019 & Acacia sp. & Senegal & This study & \\
\hline \multicolumn{6}{|l|}{ Bradyrhizobium japonicum } \\
\hline NZP 5533 & 6136 & Glycine $\max$ & & & $12 \mathrm{E}$ \\
\hline NZP $5549^{\mathrm{T}}$ & $6138^{\mathrm{T}}$ & Glycine hispida & Japan & & $12 \mathrm{~B}$ \\
\hline USDA 135 & 8321 & Glycine $\max$ & United States & & \\
\hline \multicolumn{6}{|l|}{ Bradyrhizobium elkanii } \\
\hline USDA $76^{\mathrm{T}}$ & $6134^{\mathrm{T}}$ & Glycine $\max$ & & & $12 \mathrm{E}$ \\
\hline USDA 31 & 6135 & Glycine $\max$ & United States & & $12 \mathrm{E}$ \\
\hline \multicolumn{6}{|l|}{ Bradyrhizobium sp. } \\
\hline BR 809 & 9950 & Leucaena leucocephala & Brazil & 31 & 5 \\
\hline INPA 522B & 10114 & Swartzia polyphylla & Brazil & 31 & 5 \\
\hline INPA 523B & 10115 & Swartzia polyphylla & & 31 & 5 \\
\hline NZP 2309 & 6128 & Lotus pedunculatus & Australia & & \\
\hline NZP 2314 & 6129 & Lotus uliginosus & Australia & & \\
\hline BR 5202 & 9990 & Erythrina speciosa & & 31 & 17 \\
\hline BR 5205 & 9991 & Erythrina speciosa & Brazil & 31 & 17 \\
\hline BR 5609 & 9997 & Albizia falcata & Brazil & 31 & 16 \\
\hline BR 5611 & 9998 & Albizia falcata & Brazil & 31 & 15 \\
\hline FL 27 & 10023 & Melanoxylon sp. & Brazil & 31 & 15 \\
\hline FL 276 & 10025 & Abrus sp. & Brazil & 31 & 15 \\
\hline FL 281 & 10026 & Abrus sp. & Brazil & 31 & 15 \\
\hline INPA 198A & 10080 & Ormosia macrocalyx & Brazil & 31 & 22 \\
\hline INPA 223A & 10085 & Pentaclethra macroloba & Brazil & 31 & 22 \\
\hline INPA 306A & 10092 & Swartzia schomburgkii & Brazil & 31 & 20 \\
\hline INPA 549A & 10118 & Tachigalia paniculata & Brazil & 31 & 23 \\
\hline INPA 553A & 10119 & Tachigalia paniculata & Brazil & 31 & 23 \\
\hline INPA 589A & 10139 & Clathrotropis nitida & Brazil & 31 & 20 \\
\hline \multicolumn{6}{|l|}{ Rhizobium sp. } \\
\hline BR 811 & 9951 & Leucaena leucocephala & Brazil & 31 & 18 \\
\hline BR 814 & 9952 & Leucaena leucocephala & Brazil & 31 & 7 \\
\hline BR 817 & 9953 & Leucaena leucocephala & Brazil & 31 & 18 \\
\hline BR 819 & 9954 & Leucaena leucocephala & Brazil & 31 & 3 \\
\hline BR 827 & 9956 & Leucaena leucocephala & Brazil & 31 & 18 \\
\hline BR 3614 & 9964 & Acacia decurrens & Brazil & 31 & 21 \\
\hline BR 4301 & 9978 & Calliandra callothirsus & Brazil & 31 & 7 \\
\hline BR 5401 & 9993 & Sesbania marginata & Brazil & 31 & 14 \\
\hline BR 5404 & 9994 & Sesbania marginata & Brazil & 31 & 14 \\
\hline BR 6001 & 10000 & Lonchocarpus sp. & Brazil & 31 & 7 \\
\hline BR 6806 & 10007 & Pithecellobium dulce & Brazil & 31 & 3 \\
\hline BR 8005 & 10012 & Clitoria racemosa & Brazil & 31 & 11 \\
\hline BR 8006 & 10013 & Clitoria racemosa & Brazil & 31 & 11 \\
\hline BR 8802 & 10020 & Gliricidia sepium & Brazil & 31 & 7 \\
\hline BR 8803 & 10022 & Gliricidia sepium & Brazil & 31 & 7 \\
\hline INPA 133B & 10062 & Leucaena leucocephala & Brazil & 31 & 15 \\
\hline BR 3459a & 10131 & Mimosa foliculosa & Brazil & 31 & 21 \\
\hline BR 8801 & 10132 & Gliricidia sepium & Brazil & 31 & 7 \\
\hline INPA 95A & 10134 & Leucaena pulvurulenta & Brazil & 31 & 15 \\
\hline \multicolumn{6}{|l|}{ Sinorhizobium fredii } \\
\hline USDA $205^{\mathrm{T}}$ & $6217^{\mathrm{T}}$ & Glycine $\max$ & People's Republic of China & & 18 \\
\hline USDA 191 & 8317 & Soil & People's Republic of China & & \\
\hline Rhizobium huakuii IAM $14158^{\mathrm{T}}$ & $14107^{\mathrm{T}}$ & Astragalus sinicus & People's Republic of China & 4 & \\
\hline \multicolumn{6}{|l|}{ Rhizobium galegae } \\
\hline HAMBI $540^{\mathrm{T}}$ & $6214^{\mathrm{T}}$ & Galega orientalis & Finland & & 8 \\
\hline HAMBI 1147 & 6215 & Galega orientalis & USSR & & 8 \\
\hline \multicolumn{6}{|l|}{$\begin{array}{l}\text { Rhizobium leguminosarum } \\
\text { biovar trifolii }\end{array}$} \\
\hline NZP 1 & 6119 & Trifolium repens & & & 10 \\
\hline ATCC 14480 & 8820 & Trifolium pratens & & & 10 \\
\hline $\begin{array}{l}\text { Rhizobium leguminosarum } \\
\text { biovar viciae ATCC } 10004^{T}\end{array}$ & $8817^{\mathrm{T}}$ & Pisum sativum & & & 10 \\
\hline
\end{tabular}


TABLE 1-Continued

\begin{tabular}{|c|c|c|c|c|c|}
\hline Strain $^{a}$ & LMG no. & Host plant or source ${ }^{b}$ & Geographical origin $^{b}$ & Reference $^{b}$ & PAGE group $^{c}$ \\
\hline $\begin{array}{l}\text { Rhizobium leguminosarum biovar } \\
\text { phaseoli Erd. } 316 \mathrm{C} 10 \mathrm{a}\end{array}$ & 4285 & Phaseolus vulganis & & & 10 \\
\hline \multicolumn{6}{|l|}{ Rhizobium loti } \\
\hline $3 \mathrm{~F} 6 \mathrm{~g} 2$ & 4284 & Caragana arborescens & Colorado & & 4 \\
\hline NZP 2230 & 6126 & Lotus maroccanus & Morocco & & \\
\hline NZP $2213^{\mathrm{T}}$ & $6125^{\mathrm{T}}$ & Lotus corniculatus & New Zealand & & 4 \\
\hline \multicolumn{6}{|l|}{ Sinorhizobium meliloti } \\
\hline NZP 4009 & 6130 & Medicago sativa & Australia & & 19 \\
\hline NZP $4027^{\mathrm{T}}$ & $6133^{\mathrm{T}}$ & Medicago sativa & & & 19 \\
\hline $3 \mathrm{DOa} 30$ & 4266 & Medicago sativa & & & \\
\hline \multicolumn{6}{|l|}{ Rhizobium tropici group a } \\
\hline CNPAF 119 & 9502 & Phaseolus vulgaris & Brazil & 31 & 6 \\
\hline CFN 299 & 9517 & Phaseolus vulgaris & & 30 & 6 \\
\hline $\mathrm{T} 2 \mathrm{~A} 10$ & 10336 & Phaseolus vulgaris & & & 6 \\
\hline \multicolumn{6}{|l|}{ Rhizobium tropici group b } \\
\hline $\mathrm{C}-\mathrm{O} 5$ & 9518 & Phaseolus vulgaris & & & 6 \\
\hline BR 2611 & 9519 & Phaseolus vulgaris & & & 6 \\
\hline CIAT $899^{\mathrm{T}}$ & $9503^{\mathrm{T}}$ & Phaseolus vulgaris & & 30 & 6 \\
\hline \multicolumn{6}{|l|}{ Azorhizobium caulinodans } \\
\hline ORS $571^{\mathrm{T}}$ & $6465^{\mathrm{T}}$ & Sesbania rostrata & Senegal & 14 & 9 \\
\hline FY12 & 11352 & Sesbania rostrata & Senegal & 36 & \\
\hline ORS 470 & 11818 & Sesbania rostrata & Senegal & This study & \\
\hline ORS 478 & 11820 & Sesbania rostrata & Senegal & This study & \\
\hline ORS 491 & 11823 & Sesbania rostrata & Senegal & This study & \\
\hline Azorhizobium sp. strain SG05 & 11355 & Sesbania rostrata & Senegal & 36 & \\
\hline \multicolumn{6}{|l|}{ Agrobacterium biovar 1} \\
\hline \multicolumn{6}{|l|}{ Agrobacterium tumefaciens } \\
\hline $\mathrm{B} 6^{\mathrm{T}}$ & $187^{\mathrm{T}}$ & & & & \\
\hline ICPB TT111 & 196 & & & & \\
\hline $\mathrm{B} 2 \mathrm{a}$ & 268 & & & & \\
\hline IIChrysanthemum & 303 & & & & \\
\hline \multicolumn{6}{|l|}{ Agrobacterium radiobacter } \\
\hline ATCC $19358^{\mathrm{T}}$ & $140^{\mathrm{T}}$ & & & & \\
\hline Bernaerts M $2 / 1$ & 147 & & & & \\
\hline \multicolumn{6}{|l|}{ Agrobacterium biovar 2} \\
\hline Agrobacterium sp. strain Kerr 38 & 161 & & & & \\
\hline Agrobacterium tumefaciens Apple 185 & 219 & & & & \\
\hline Agrobacterium rhizogenes ATCC $11325^{\mathrm{T}}$ & $150^{\mathrm{T}}$ & & & & \\
\hline Agrobacterium rubi ATCC $13335^{\mathrm{T}}$ & $156^{\mathrm{T}}$ & & & & \\
\hline \multicolumn{6}{|l|}{ Agrobacterium vitis } \\
\hline Pan. AG61 & 257 & & & & \\
\hline Pan. AG63 & 258 & & & & \\
\hline \multicolumn{6}{|l|}{ Agrobacterium (separate taxa) } \\
\hline \multicolumn{6}{|l|}{ Agrobacterium tumefaciens } \\
\hline NCPPB 1771 & 233 & & & & \\
\hline Zutra 3I/A & 198 & & & & \\
\hline \multicolumn{6}{|l|}{ Agrobacterium radiobacter } \\
\hline CDC A6597 & 383 & & & & \\
\hline CDC C7258 & 385 & & & & \\
\hline Mycoplana dimorpha $\mathrm{NCIB} 9439^{\mathrm{T}}$ & $4061^{\mathrm{T}}$ & & & & \\
\hline Mycoplana ramosa NCIB $9440^{\mathrm{T}}$ & $3026^{\mathrm{T}}$ & & & & \\
\hline
\end{tabular}


TABLE $1-$ Continued

\begin{tabular}{|c|c|c|c|c|c|}
\hline Strain $^{a}$ & LMG no. & Host plant or source ${ }^{b}$ & Geographical origin $^{b}$ & Reference $^{b}$ & PAGE group $^{c}$ \\
\hline \multicolumn{6}{|l|}{ Ochrobactrum anthropi } \\
\hline AB 940 & 33 & & & & \\
\hline AB 1196 & 34 & & & & \\
\hline AB 1293 & 35 & & & & \\
\hline CCUG 7349 & 2136 & & & & \\
\hline CNS 2.75 & 3301 & & & & \\
\hline CNS 23.76 & 3306 & & & & \\
\hline CIP 8174 & 3329 & & & & \\
\hline CIP 110.77 & 3330 & & & & \\
\hline CIP $14970^{\mathrm{T}}$ & $3331^{\mathrm{T}}$ & & & & \\
\hline CIP 353.75 & 3333 & & & & \\
\hline Phyllobacterium myrcinacearum & $2(\mathrm{t} 1)$ & & & & \\
\hline NCIB 12127 & 3 & & & & \\
\hline $\begin{array}{l}\text { Phyllobacterium rubiacearum } \\
\text { NCIB } 12128^{\mathrm{T}}\end{array}$ & $1(\mathrm{t} 1)^{\mathrm{T}}$ & & & & \\
\hline \multicolumn{6}{|l|}{ Phyllobacterium sp. } \\
\hline PGSB 6270 & 8227 & & & & \\
\hline PGSB 3714 & 8231 & & & & \\
\hline
\end{tabular}

${ }^{a}$ ATCC, American Type Culture Collection, Rockville, Md.; BR and FL, strains from the CNPBS/EMBRAPA, Centro Nacional de Pesquisa em Biologia do Solo, Seropedica, Rio de Janeiro, Brazil, and the Emprasa Brasiliera de Pesquisa Agropequaria; CFN, Centrode Investigacion sobre Fijacion de Nitrogeno, Universidad Nacional Autonoma de Mexico, Cuernavaca, Mexico; CIAT, Rhizobium Collection, Centro International de Agricultura Tropical, Cali, Colombia; HAMBI, Culture Collection of the Department of Microbiology, University of Helsinki, Helsinki, Finland; INPA, National Institute of Amazonia Research, Manaus, Brazil; LMG, Collection of Bacteria of the Laboratorium voor Microbiologie, University of Ghent, Ghent, Belgium; NZP, Culture Collection of the Department for Scientific and Industrial Research, Biochemistry Division, Palmerston North, New Zealand; ORS, ORSTOM Collection, Institut Français de Recherche Scientifique pour le Développement en Coopération, Dakar, Senegal; Pan., C. Panagopoulos, Crete, Greece; USDA, U.S. Department of Agriculture, Beltsville, Md.

${ }^{b}$ Information is given only when it is known and/or meaningful.

${ }^{c}$ PAGE group of Moreira et al. (31).

${ }^{d}$ In a second subculture of strain ORS $609^{\mathrm{T}}\left(=\mathrm{LMG} 7837^{\mathrm{T}}\right)$, two stable colony types were isolated. The protein profiles of these colony types were identical.

Sesbania grandiflora, $60 \mathrm{~min}$; Neptunia oleracea, $30 \mathrm{~min}$; and Leucaena leucocephala, $30 \mathrm{~min}$. After acid treatment, the seeds were washed with water until all traces of acid were removed. The seeds were incubated so that they would germinate in sterile petri dishes on $1 \%$ water agar for 24 to $48 \mathrm{~h}$ and then were transferred to tubes containing Jensen seedling slant agar (42) for root nodulation trials ( 8 to 10 plants were routinely tested with each strain). Root nodules appeared ca. 10 to 20 days after inoculation, and 3 weeks later the nodules were fully developed.

Auxanographic tests. API galleries (API 50CH, API 50AO and API 50AA; bioMérieux, Montalieu-Vercieu, France) were used to determine whether 147 organic compounds were utilized as sole carbon sources, as described previously (22). Inocula were obtained from 36-h YMA slant cultures. After inoculation, the galleries were incubated at $30^{\circ} \mathrm{C}$, and results were determined after 1, 2, 4, and 7 days. About 20 strains were included in duplicate on separate occasions to verify the reproducibility of the tests.

The results of the auxanographic tests were scored as described previously (22). The levels of interstrain similarity $(S)$ were calculated by using a similarity distance coefficient derived from the Canberra metric coefficient $\left(d_{\text {Canb }}\right)(40)$, as follows: $S=100 \times\left(1-d_{\text {Canb }}\right)$. A cluster analysis was performed by using the unweighted average pair group method (41), the Clustan 2.1 program of Wishart (45), and the Siemens model 7570-C computer of the Centraal Digitaal Rekencentrum, Universiteit Gent, Ghent, Belgium.

DNA base composition. Cells were grown for 2 to 3 days in Roux flasks on TY medium. High-molecular-weight DNA was prepared by the method of Marmur (28). The guanine-pluscytosine $(\mathrm{G}+\mathrm{C})$ content of the DNA was determined by the thermal denaturation method (12) and was calculated by using the equation of Marmur and Doty (29), as modified by De Ley (8). DNA from Escherichia coli LMG 2093 was used as a reference.

DNA-rRNA hybridization. High-molecular-weight DNA was purified by $\mathrm{CsCl}$ gradient centrifugation, denatured, and fixed on cellulose nitrate filters (type SM 11358; Sartorius, Göttingen, Germany) as described previously (11). A ${ }^{3} \mathrm{H}$-labeled $23 \mathrm{~S}$ rRNA probe was prepared from Sinorhizobium teranga ORS 22 by in vivo labeling with $\left[5,6-{ }^{3} \mathrm{H}\right]$ uracil in medium $\mathrm{C}$ containing (per liter) $30 \mathrm{~g}$ of glucose, $3 \mathrm{~g}$ of peptone, $3 \mathrm{~g}$ of $\left(\mathrm{NH}_{4}\right)_{2} \mathrm{SO}_{4}, 0.2 \mathrm{~g}$ of $\mathrm{KH}_{2} \mathrm{PO}_{4}, 0.8 \mathrm{~g}$ of $\mathrm{K}_{2} \mathrm{HPO}_{4}, 0.1 \mathrm{~g}$ of $\mathrm{CaSO}_{4} \cdot 2 \mathrm{H}_{2} \mathrm{O}, 10^{-4} \mathrm{~g}$ of $\mathrm{FeCl}_{3} \cdot 6 \mathrm{H}_{2} \mathrm{O}$, and $5 \times 10^{-3} \mathrm{~g}$ of $\mathrm{Na}_{2} \mathrm{MoO}_{4} \cdot 2 \mathrm{H}_{2} \mathrm{O}$. The specific activity of the probe was $160,000 \mathrm{dpm}$. The $23 \mathrm{~S}$ rRNA probe was prepared and purified as described previously (19). The following other rRNA probes were available from members of our research group: ${ }^{3} \mathrm{H}$ labeled 23S rRNA from $R$. meliloti LMG 6130 and ${ }^{3} \mathrm{H}$-labeled 23S rRNA from strain LMG 6123. Hybridizations were performed as described by De Ley and De Smedt (11). The temperature at which $50 \%$ of the DNA-rRNA hybrid was denatured under standard conditions $\left[T_{m(e)}\right]$ was the decisive taxonomic parameter.

Analysis of 16S rRNA genes. The $16 \mathrm{~S}$ rRNA gene sequences of the following five strains were determined: Sinorhizobium teranga ORS 22 and ORS $1009^{\mathrm{T}}(\mathrm{T}=$ type strain), strains ORS 1001 and ORS 1002, and Sinorhizobium saheli ORS 609 ${ }^{\mathrm{T}}$. A large fragment of the $16 \mathrm{~S}$ rRNA gene (positions 21 to $1521 ; E$. coli numbering system [3]) was amplified by a PCR and sequenced directly as described previously $(43,44)$. The sequences determined, together with reference sequences obtained from the EMBL data library, were aligned by using the PILEUP, PRETTY, and UGLY programs in the Genetics Computer Group sequence analysis package (13). The align- 
ment was verified and corrected manually. In all, a continuous stretch of 1,401 positions (including gaps) was used for further analysis. Distances were calculated by using the DNADIST program of the Phylogeny Inference Package (16). The programs DNABOOT, NEIGHBOR, and CONSENCE of the same package were used to produce an unrooted phylogenetic tree. Similarity values were calculated by using the GAP program in the Genetics Computer Group package.

DNA-DNA hybridization. DNA-DNA hybridizations were performed by the initial renaturation rate method (10). Renaturations experiments in which approximately $50 \mu \mathrm{g}$ of DNA per $\mathrm{ml}$ was used were carried out at $79.8^{\circ} \mathrm{C}$, which is the optimal renaturation temperature in $2 \times$ SSC $(1 \times$ SSC is 0.15 $\mathrm{M} \mathrm{NaCl}$ plus $0.015 \mathrm{M}$ sodium citrate, $\mathrm{pH} 7$ ).

Nucleotide sequence accession numbers. The newly determined 16S rRNA sequences were deposited in the EMBL Data Library under accession numbers X68387 to X68391.

\section{RESULTS}

Isolation of rhizobia from root nodules of Sesbania spp. and Acacia spp. About 80 isolates were obtained from different ecological areas of Senegal either by directly isolating them from naturally occurring nodules or by trapping them on young plants grown in the presence of soil samples. A total of 52 strains, which we placed in three clusters (as determined by SDS-PAGE and auxanography [see below]), were studied further. These strains are listed in Table 1. Fifteen of these strains originated from different Sesbania species (Sesbania rostrata, Sesbania cannabina, Sesbania aculeata, Sesbania sesban, Sesbania pachycarpa, Sesbania grandiflora), and 37 originated from different Acacia species (Acacia senegal, Acacia seyal, Acacia raddiana, Acacia horrida, Acacia mollissima, Acacia laeta).

SDS-PAGE of total bacterial proteins. The SDS-PAGE whole-cell protein patterns of the 80 rhizobial isolates obtained from Senegal were scanned and analyzed numerically, together with the patterns of 67 reference strains available in our database, which represented the different Rhizobium, Bradyrhizobium, and Azorhizobium groups and the new protein electrophoretic clusters identified among the fast growers by Moreira et al. (31). Representative strains belonging to phenotypic cluster 3 described by Dreyfus et al. (14) (strains ORS 22, ORS 52, and ORS 53) were also included, as were ORS $609^{\mathrm{T}}$ and ORS 611 [the $T_{m(e)}$ values of the DNA-rRNA hybrids between strains ORS $609^{\mathrm{T}}$ and ORS 611 and $R$. meliloti LMG 6130 have been determined previously (14)]. The reproducibility of the SDS-PAGE technique was checked by including different subcultures of the same strain and different protein extracts of one strain. In all cases such profiles were very similar (the $r$ values were between 93 and 97\%). The protein profiles of different colony morphology variants of the same strain (designated $\mathrm{t} 1$ and $\mathrm{t} 2$ ) were in most cases nearly identical or very similar (e.g., strains ORS 1014t1 and ORS 1014t2) (Fig. 1) (see below).

At or above a mean correlation coefficient ( $r$ value) of $87.5 \%$ the different Rhizobium, Bradyrhizobium, and Azorhizobium species constitute separate clusters. In addition to the members of the $R$. loti protein electrophoretic cluster containing the type strain, two other $R$. loti strains (LMG 6123 and LMG 6124 ) belong in cluster $U$ (see below). Also at this level most of the clusters of Moreira et al. (31) (designated FM followed by the original cluster numbers) were recovered; the exceptions were (i) cluster FM2, which grouped with one of our clusters (see below); (ii) cluster FM15, which was split up (two strains now belong to a new cluster, while four other strains group together with one representative strain of cluster FM16); and (iii) representative strains of clusters FM17 and FM20, which now belong to a single cluster. Azorhizobium sp. strain LMG 11355 produced a unique protein profile.

A total of 52 of the Senegalese isolates could be placed in three protein electrophoretic clusters (clusters $T, S$, and $U$ ), while the remaining 28 strains were not members of any group. Our results are presented as a similarity dendrogram in Fig. 1. For the sake of clarity, most of the 28 ungrouped Senegalese isolates are not included in Fig. 1; the only exception is strain ORS 1096, which is the closest relative of cluster $U$ as determined by its protein profile. Representative profiles are shown in Fig. 2.

Clusters $\mathrm{S}$ and $\mathrm{T}$ exhibit high levels of similarity with each other and with the $R$. meliloti protein gel electrophoretic cluster. Cluster $\mathrm{T}$ is composed of 10 isolates originating from Sesbania spp. and 13 isolates originating from Acacia spp. Cluster $\mathbf{S}$ is composed of five isolates originating from Sesbania spp.

Cluster U consists of 24 Senegalese isolates that originated from Acacia spp. (including 20 strains obtained from Acacia senegal) and contains four subclusters (subclusters U1 to U4) and one separate strain (ORS 1002). Cluster FM2 of Moreira et al. (31), which contained five strains of Brazilian rhizobia and $R$. loti LMG 6123 and LMG 6124, belongs in cluster U (subclusters U3 and U4, respectively).

Morphological and physiological characteristics. All of the cluster $\mathrm{S}, \mathrm{T}$, and $\mathrm{U}$ isolates were fast growers and grew at temperatures up to $40^{\circ} \mathrm{C}$. Cluster U strains grew at temperatures up to $42^{\circ} \mathrm{C}$, and most of the cluster $\mathrm{S}$ and $\mathrm{T}$ strains grew at temperatures up to $44^{\circ} \mathrm{C}$. Most of the strains had one or several polar or subpolar flagella.

Host specificity. The host range of cluster U strains is more or less restricted to Acacia, Leucanea, and Neptunia species, while the $\mathrm{S}$ and $\mathrm{T}$ strains are more promiscuous and are found in Sesbania, Acacia, Leucaena, and Neptunia species (27).

Numerical analysis of auxanographic results. All of the new isolates (except strains ORS 20, ORS 1073, ORS 10, and ORS 13) were tested for utilization of 147 organic compounds as sole carbon sources by using the API 50 system. The reproducibility of the tests was good. The average interstrain similarity values for strains tested in duplicate were between 88 and $92 \%$. Subcultures of the same strain obtained on different dates (and consequently with different Collection of Bacteria of the Laboratorium voor Microbiologie numbers) gave reproducible results ( 89 to $95 \%$ ). The results obtained for representative strains belonging to other Rhizobium species and related groups (including representatives of the three Agrobacterium biovars and the genera Ochrobactrum, Phyllobacterium, and Mycoplana) were available in the database of our research group and were included in the numerical analysis. The results are shown in Table 2 and in Fig. 3. At a similarity coefficient of $85 \%$, different clusters could be distinguished, and several of these clusters corresponded to clusters identified by SDSPAGE pattern analysis. The subgroups of $R$. tropici (subgroups $a$ and b) did not group together. Representative strains of the two biovars of the genus Agrobacterium, Agrobacterium rubi, and Agrobacterium vitis were members of separate auxanographic groups. All Ochrobactrum anthropi strains investigated clustered together, as did the members of the genera Phyllobacterium and Mycoplana. The correspondence between gel electrophoretic clusters $\mathrm{T}$ and $\mathrm{S}$ and the auxanographic groups was excellent; gel electrophoretic cluster $U$ was more difficult to recognize because the auxanographic results obtained for the Brazilian isolates (LMG 10093, LMG 10056, LMG 10061) belonging to protein cluster FM2 were quite different from the 
Strain no. Cluster name ${ }^{a}$

$\begin{array}{cccccc}50 & 60 & 70 & 80 & 90 & 100 \\ 1 & 1 & 1 & 1 & 1\end{array}$

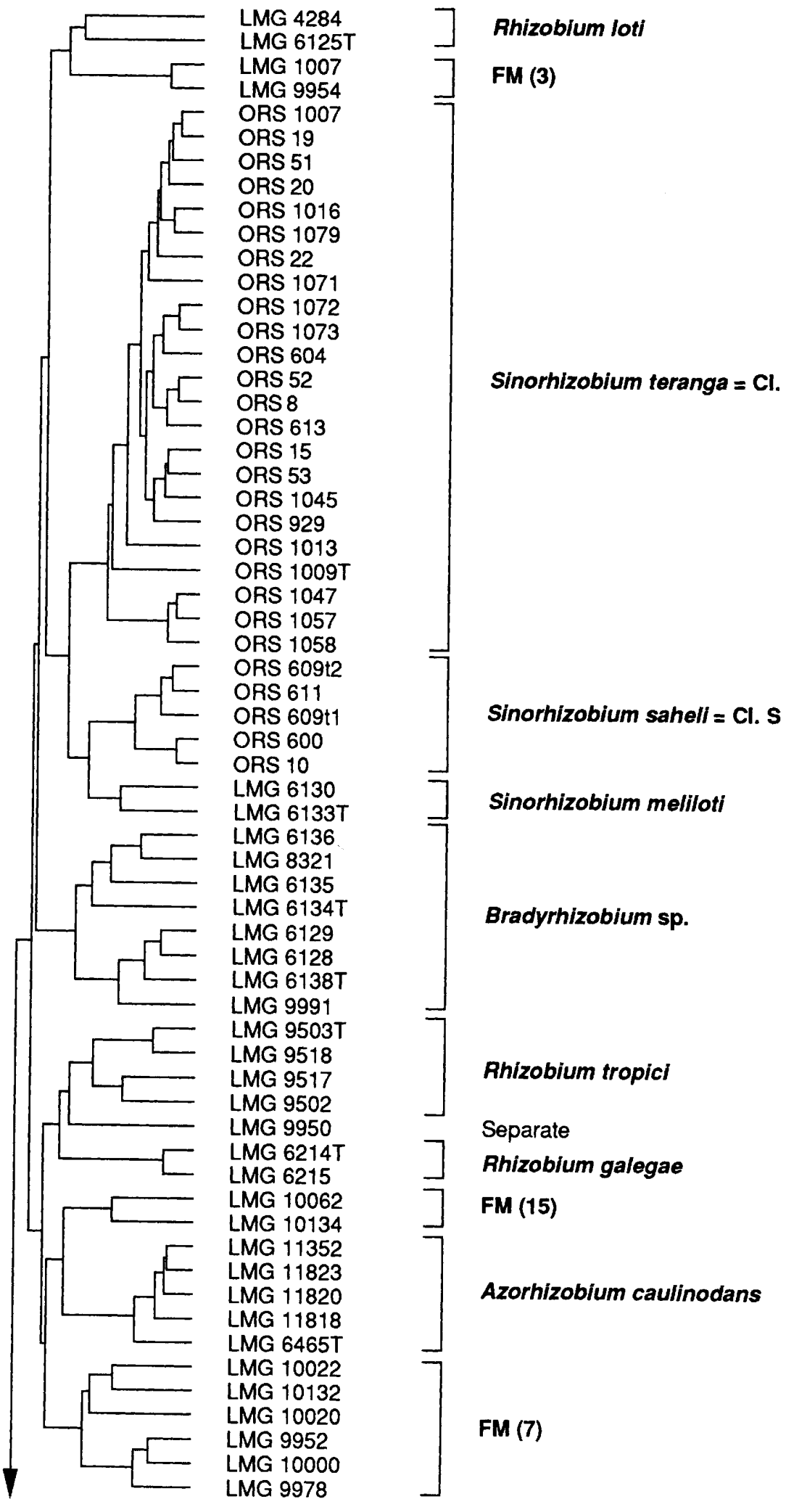




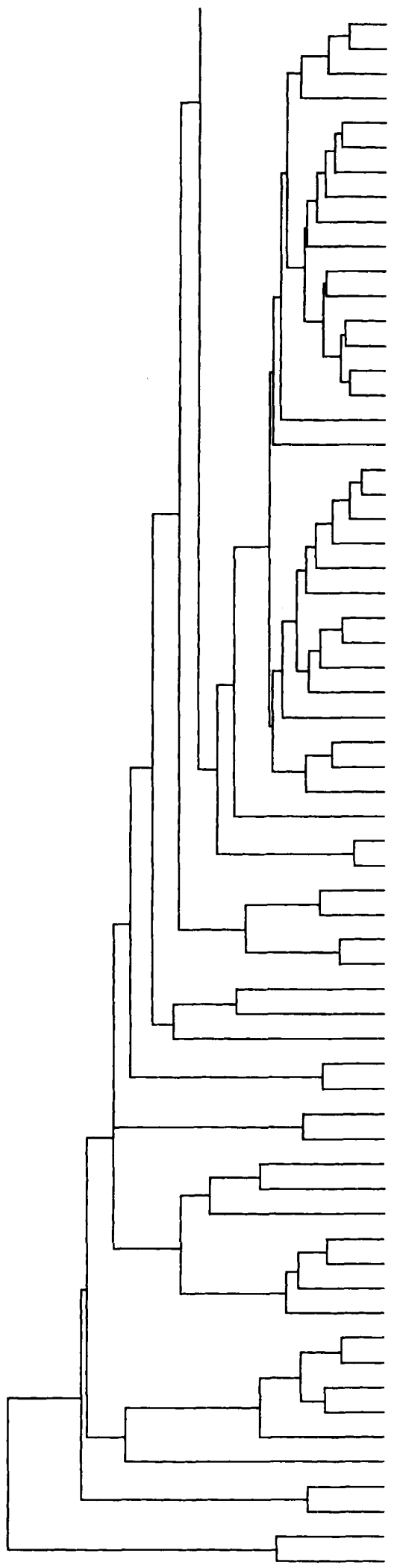

ORS 1020

ORS 1018

ORS 1015

ORS 1024

ORS 1036

ORS 1014

ORS 1037

ORS 1029

ORS 1014 t1

ORS 1035

ORS 1014 t2

ORS 1001T

ORS 1005

ORS 13

ORS 1004

ORS 1010

ORS 1088

ORS 1002

ORS 1030

ORS 1032

ORS 1031

ORS 1038

ORS 1040

LMG 10031

LMG 10056

LMG 10059

LMG 10093

LMG 9970

LMG 10061

LMG 6123

LMG 6123A

LMG 6124

ORS 1096

LMG 10115

LMG 10114

LMG 8820

LMG 6119

LMG 8817T

LMG 4285

LMG 9993

LMG 9994

LMG 6126

LMG 10012

LMG 10013

LMG 9964

LMG 10131

LMG 9990

LMG 10092

LMG 10139

LMG 9953

LMG 9956

LMG 9951

LMG 6217T

LMG 10023

LMG 9998

LMG 10025

LMG 10026

LMG 9997

LMG 11355

LMG 10080

LMG 10085

LMG 10119

LMG 10118

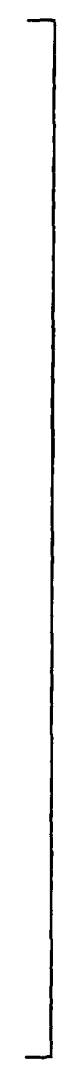

\section{Cluster U}

\section{Separate}

FM (5)

Rhizobium leguminosarum

FM (14)

Rhizobium loti

FM (11)

FM (21)

FM (17 and 20)

\section{Sinorhizobium fredii}

\section{FM (15 and16)}

\section{Azorhizobium caulinodans}

FM (22)

FM (23)

FIG. 1. Dendrogram showing the relationships among the electrophoretic protein patterns of Senegalese, Brazilian, and reference strains of Rhizobium, Bradyrhizobium, Azorhizobium, and Sinorhizobium species. The dendrogram is based on mean correlation coefficient $(r)$ values, which were grouped by the unweighted average pair group method. Positions 10 to 320 of the 400 -point traces were used to calculate the levels of similarity between individual pairs of traces. The reproducibility of the technique is illustrated by results obtained for two independent extracts of strain LMG 6123. The bar indicates $r$ values converted to percentages. Cl., cluster. 


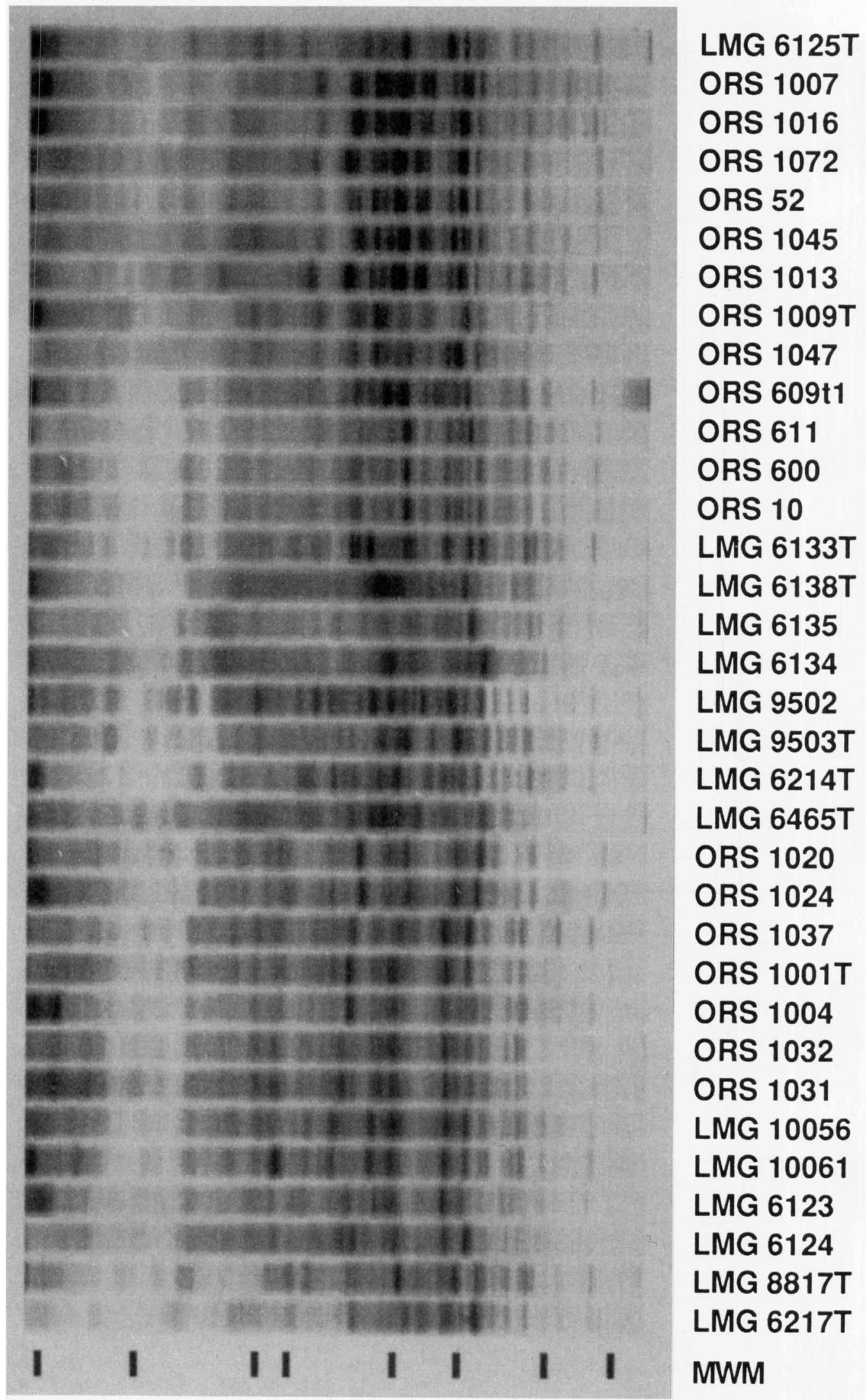


results obtained for the other members of cluster $\mathrm{U}$. A single Senegalese isolate (ORS 1029) was auxanographically the most aberrant strain in gel electrophoretic cluster U. $R$. lot $i$ LMG 6123 , another member of gel electrophoretic cluster FM2, was similar to the Senegalese isolates. Two other strains of $R$. loti, including the type strain, were auxanographically more similar to the Senegalese members of cluster $U$ than to the Brazilian members. Of the 147 carbon sources tested, 35 were utilized by all of the strains belonging to the three groups, while 59 were utilized by none. We found that xylitol, glycolate, and Lcitrulline could be used to discriminate among clusters $\mathrm{S}, \mathrm{T}$, and $U$ (Table 2). We compared our results with the data in the database available in our research group, and features that distinguish clusters $\mathrm{T}, \mathrm{S}$, and $\mathrm{U}$ and other Rhizobium species and related genera are shown in Table 2 . We found several features that distinguish clusters $\mathrm{T}$ and $\mathrm{S}$ and their closest neighbors, $R$. meliloti and $R$. fredii (utilization of erythritol, methyl-xyloside, L-sorbose, dulcitol, methyl-D-glycoside, xylitol, D-lyxose, D-tagatose, L-arabitol, 2-ketogluconate, acetate, propionate, isobutyrate, glycolate, DL-hydroxybutyrate, aconitate, $p$-hydroxybenzoate, $\mathrm{L}$-valine, L-serine, L-threonine, trigonelline, L-aspartate, L-lysine, L-citrulline, $\beta$-alanine, and DL-3-aminobutyrate). $R$. lot $i$ and cluster $U$ could not be distinguished by the results of the auxanographic tests used in this study. On the basis of previously published data and our results obtained with the type strain (Table 2), $R$. huakuii differs from $R$. loti and other members of cluster $U$ by utilizing D-melibiose, D-fucose, L-fucose, and oxalate.

$\mathrm{G}+\mathbf{C}$ contents of DNAs. The $\mathrm{G}+\mathrm{C}$ content ranges for clusters $\mathrm{T}$ and $\mathrm{U}$ were 60.8 to 61.6 and 62.6 to $63.9 \mathrm{~mol} \%$, respectively (Table 3 ). Two representative strains of cluster $\mathrm{S}$ had a $\mathrm{G}+\mathrm{C}$ content of $65.7 \mathrm{~mol} \%$ (Table 3 ).

DNA-rRNA hybridization. In order to determine the genetic relationships among clusters $S, T$, and $U$ and the different Rhizobium species, we performed DNA-rRNA hybridization experiments with an rRNA probe from cluster T strain ORS 22 and other rRNA probes available from members of our research group (one from $R$. meliloti LMG 6130 and one from strain LMG 6123, representing cluster $U$ ). The results are shown in Table 3.

Cluster $\mathrm{U}$ could not be differentiated from $R$. loti on the basis of DNA-rRNA hybridization data. In fact, strain LMG 6123 has been described as a member of $R$. lot $i$ by Crow et al. (6) and has been used previously (19) to prepare a labeled rRNA probe to differentiate the $R$. loti rRNA branch that is the most divergent branch $(9,14)$ in the Rhizobium-Agrobacterium rRNA cluster. As expected from their similar protein profiles, cluster $\mathrm{T}$ strains had indistinguishable $T_{m(e)}$ values when rRNA from strain ORS 22 was used. Both cluster $S$ and cluster $T$ are rather closely related to $R$. meliloti.

$16 S$ rRNA gene sequencing. The $16 \mathrm{~S}$ rRNA sequences which we determined were compared with the $16 \mathrm{~S}$ rRNA sequences of other members of the alpha 2 subclass of the Proteobacteria available from the EMBL Data Library. Figure 4 is a tree showing the phylogenetic positions of the new isolates within the alpha 2 subclass of the Proteobacteria. Representatives of cluster T (strains ORS 22 and ORS $1009^{\mathrm{T}}$ ) and cluster S (strain ORS $609^{\mathrm{T}}$ ) were found to be closely related but nevertheless members of distinct species within the $R$. fredii- $R$. meliloti lineage (level of sequence similarity, $98.9 \%$, corresponding to 17 differences in a comparison of 1,436 bases). The levels of sequence similarity between cluster $\mathrm{S}$ and $R$. meliloti and between cluster $\mathrm{S}$ and $R$. fredii were $98.3 \%$ (24 differences in a comparison of 1,436 bases) and $99.2 \%$ (11 differences in a comparison of 1,436 bases), respectively; and the levels of sequence similarity between cluster $\mathrm{T}$ and $R$. meliloti and between cluster $\mathrm{T}$ and $R$. fredii were $97.6 \%$ (34 differences in a comparison of 1,436 bases) and $98.4 \%$ ( 24 differences in a comparison of 1,437 bases), respectively. For comparison, the level of sequence similarity between $R$. meliloti and $R$. fredii was $99.0 \%$ (15 differences in a comparison of 1,437 bases). Cluster U strains ORS 1001 (subcluster U1) and ORS 1002 (subcluster U2) exhibited high levels of sequence similarity with $R$. huakuii (99.6\%, corresponding to 7 differences in 1,430 bases) and $R$. loti (98.0\%, corresponding to 25 differences in 1,436 bases). The level of sequence similarity between $R$. loti and $R$. huakuii was $98.3 \%$ (24 differences in a comparison of 1,428 bases). The partial sequences (positions 350 to 850 ) of two representative strains of subclusters U3 (LMG 6123) and U4 (LMG 10056) were also determined, and the close phylogenetic relatedness of these organisms to strains ORS 1001 and ORS 1002 was confirmed ( 0 or 1 differences in a comparison of 500 nucleotides).

DNA-DNA hybridization. As Table 4 shows, we found high levels of DNA-DNA binding (79 to $100 \%$ ) within clusters T and S. Representative DNAs of members of clusters T and S did not hybridize to significant degrees with each other or with the DNAs of $R$. meliloti and $R$. fredii (levels of hybridization, less than $25 \%$ ), which are their closest phylogenetic relatives (Fig. 4). However, considerable genetic heterogeneity was evident within cluster $U$. Our hybridization results indicated that strains belonging to subclusters $U 1$ and $U 2$ certainly belong to a single species and that members of subcluster U3 exhibit significant levels of DNA binding (mean, 37\%) with members of clusters U1 and U2. For strain LMG 6123 (subcluster U4) the mean level of DNA binding with members of the other subclusters (23\%) was not significant (values less than $25 \%$ are not significant when the initial renaturation method is used). Representative members of cluster $U$ exhibited no significant level of DNA binding with the type strain of $R$. loti, which is their closest phylogenetic relative (Fig. 4). Because the other Rhizobium species are further removed from the $R$. loti subcluster (Fig. 4), we presumed that there would be no significant levels of DNA-DNA binding between cluster $U$ strains and strains belonging to the other Rhizobium species; consequently, such hybridization experiments were not performed.

\section{DISCUSSION}

We used a polyphasic approach to study the taxonomic relationships of new rhizobial isolates obtained from Senegal. SDS-PAGE of total proteins was a fast method which was used to identify groups and to compare new results with data obtained from our large database. In order to describe and differentiate the new groups, we performed auxanographic

FIG. 2. Computer-processed print-out of positions 0 (top of gel, right side of the pattern) to 350 (bottom of gel, left side of the pattern) of the digitized and normalized protein patterns obtained for representative strains of the different clusters. Lane MWM contained mixture of molecular weight markers that included (from right to left) $\beta$-galactosidase (molecular weight, 116,000$)$, bovine albumin $(66,000)$, egg albumin $(45,000)$, glyceraldehyde-3-phosphate dehydrogenase $(36,000)$, carbonic anhydrase $(29,000)$, trypsinogen $(24,000)$, trypsin inhibitor $(20,100)$, and lysozyme (14,500). 
TABLE 2. Results of carbon assimilation tests performed with Sinorhizobium teranga, Sinorhizobium saheli, cluster U strains, and Agrobacterium, Azorhizobium, Mycoplana, Ochrobactrum, Phyllobacterium, Sinorhizobium, and Rhizobium reference strains

\begin{tabular}{|c|c|c|c|c|c|c|c|c|c|c|c|c|c|c|c|c|c|}
\hline \multirow[b]{2}{*}{ Substrate $^{a}$} & \multicolumn{17}{|c|}{ Utilization by: } \\
\hline & 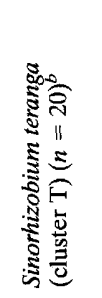 & 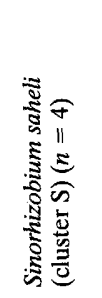 & 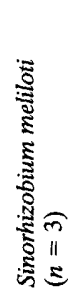 & 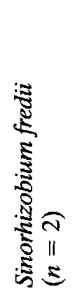 & 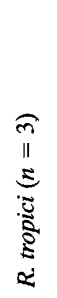 & 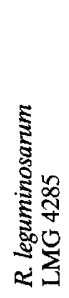 & 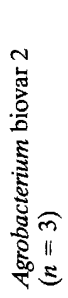 & 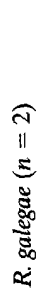 & 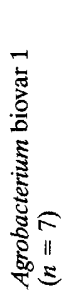 & 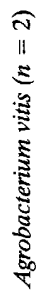 & 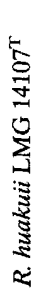 & 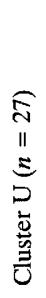 & 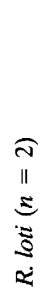 & 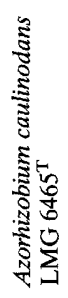 & 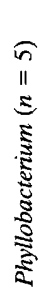 & 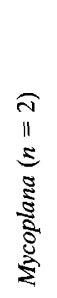 & 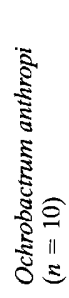 \\
\hline Glycerol & $t^{c}$ & + & + & + & + & + & 66 & + & + & + & + & + & + & + & + & + & + \\
\hline Erythritol $^{d, e}$ & - & - & + & 50 & + & - & + & - & - & - & - & - & 50 & - & - & - & + \\
\hline D-Arabinose ${ }^{d}$ & + & + & + & 50 & + & + & + & + & + & 50 & + & + & + & - & + & - & + \\
\hline Ribose & + & + & + & + & + & + & + & + & + & + & + & + & + & - & + & 50 & + \\
\hline $\mathrm{L}-\mathrm{Xylose}^{d}$ & $75(+)^{f}$ & $25(-)$ & 33 & - & + & + & + & - & 50 & 50 & + & + & + & - & - & - & - \\
\hline Methyl-D-xyloside ${ }^{d, e}$ & - & - & + & + & + & + & + & + & + & - & - & - & - & - & - & - & - \\
\hline D-Mannose & + & + & + & + & + & + & + & + & + & + & + & + & + & - & + & + & + \\
\hline L-Sorbose $\mathrm{e}^{d, e}$ & - & - & + & - & - & - & + & - & 75 & - & - & 33 & 50 & - & - & 50 & - \\
\hline Rhamnose & + & + & + & + & + & + & + & + & + & + & + & + & + & - & + & - & + \\
\hline Dulcitol $^{d, e}$ & - & - & + & - & - & + & 66 & - & + & - & + & 63 & - & - & + & - & + \\
\hline Inositol $^{d}$ & + & + & + & + & + & + & + & + & + & + & + & + & + & - & + & 50 & + \\
\hline Mannitol & + & + & + & 50 & + & + & + & + & + & + & + & + & + & - & + & + & + \\
\hline Sorbitol & + & + & + & 50 & 66 & + & + & + & + & + & + & + & + & - & + & + & + \\
\hline Methyl-D-mannoside ${ }^{d}$ & - & - & - & - & - & + & - & - & - & 50 & - & - & - & - & - & - & - \\
\hline Methyl-D-glucoside ${ }^{d, e}$ & $35(+)$ & - & + & - & 33 & - & + & - & + & - & - & 33 & 50 & - & + & - & 65 \\
\hline$N$-acetylglucosamine ${ }^{d}$ & + & + & + & + & + & - & + & + & + & + & + & + & + & - & + & + & + \\
\hline Amygdalin ${ }^{d}$ & $40(-)$ & - & - & - & - & - & + & - & + & 50 & - & - & - & - & - & - & - \\
\hline Arbutin ${ }^{d}$ & + & + & + & + & + & + & + & - & + & + & + & 15 & 50 & - & - & - & - \\
\hline Salicin $^{d}$ & $50(+)$ & $25(-)$ & + & + & - & - & 33 & - & + & + & - & 15 & - & - & - & - & - \\
\hline D-Cellobiose $\mathrm{e}^{d}$ & + & + & + & + & + & + & + & + & + & + & + & + & + & - & + & - & + \\
\hline Maltose $\mathrm{e}^{d}$ & + & + & + & + & 66 & + & + & + & + & + & + & + & + & - & + & - & + \\
\hline Lactose $^{d}$ & + & + & + & + & 66 & + & + & + & + & + & + & + & + & - & - & - & - \\
\hline D-Melibiose ${ }^{d}$ & + & + & + & + & + & + & + & + & + & + & - & + & 50 & - & - & - & - \\
\hline Sucrose $\mathrm{e}^{d}$ & + & + & + & + & + & + & + & + & + & + & + & + & + & - & + & - & + \\
\hline Trehalose $^{d}$ & + & + & + & + & + & + & + & + & + & + & + & + & + & - & + & - & + \\
\hline D-Melezitose ${ }^{d}$ & $35(+)$ & $50(-)$ & + & 50 & - & - & - & - & + & - & - & - & - & - & 40 & - & - \\
\hline D-Raffinose ${ }^{d}$ & + & + & + & + & + & + & + & + & + & + & + & 44 & - & - & - & - & - \\
\hline Xylitol $^{d, e}$ & + & - & + & - & + & + & + & + & + & - & + & + & 50 & - & + & - & - \\
\hline$\beta$-Gentiobiose ${ }^{d}$ & $35(+)$ & $50(-)$ & + & + & 66 & + & 33 & + & + & 50 & + & 63 & 50 & - & 60 & - & 80 \\
\hline D-Turanose ${ }^{d}$ & + & + & + & + & + & + & + & + & + & + & + & + & + & - & + & - & + \\
\hline D-Lyxose $e^{d, e}$ & $70(w)$ & $50(-)$ & + & - & + & + & + & + & + & + & + & + & + & - & 40 & + & + \\
\hline D-Tagatose ${ }^{d, e}$ & - & - & + & - & - & + & + & - & + & - & - & 74 & - & - & + & - & + \\
\hline D-Fucose $\mathrm{e}^{d}$ & - & - & 66 & 50 & 33 & - & + & + & + & + & - & 67 & + & - & + & - & + \\
\hline L-Arabitol ${ }^{d, e}$ & - & - & + & + & + & + & + & - & + & - & + & 26 & + & - & 60 & - & - \\
\hline Gluconate $^{d}$ & $50(+)$ & $25(+)$ & - & - & + & + & + & + & + & + & - & 11 & - & + & + & - & + \\
\hline 2-Ketogluconate e $^{d, e}$ & + & $25(+)$ & + & - & - & - & + & + & + & 50 & - & 15 & 50 & + & + & 50 & + \\
\hline 5-Ketogluconate ${ }^{d}$ & - & - & - & - & - & - & + & - & + & - & - & - & - & + & 80 & - & 80 \\
\hline Acetate $^{d, e}$ & + & + & 33 & - & 33 & - & - & + & + & + & - & 81 & + & + & + & + & + \\
\hline Propionate $^{d, e}$ & $40(-)$ & + & 33 & - & - & - & - & - & + & - & - & 15 & - & + & 60 & - & + \\
\hline Butyrate $^{d}$ & $15(-)$ & - & - & - & - & - & - & 50 & - & + & - & 18 & - & + & + & 50 & + \\
\hline Isobutyrate $^{d, e}$ & $70(+)$ & + & 66 & - & - & - & - & - & - & - & - & 22 & - & + & + & - & + \\
\hline$n$-Valerate ${ }^{d}$ & - & - & - & - & - & - & - & - & - & - & - & 11 & - & + & + & - & + \\
\hline Isovalerate $^{d}$ & - & - & - & - & - & - & - & - & - & - & - & - & - & - & + & - & - \\
\hline Oxalate $^{d}$ & - & - & - & - & - & - & - & - & - & - & + & - & - & - & - & - & - \\
\hline Caprate $^{d}$ & - & - & - & - & - & - & - & - & - & - & - & - & - & - & - & - & + \\
\hline Malonate & - & - & - & - & - & - & 33 & - & - & - & - & - & - & - & - & - & - \\
\hline Succinate $^{d}$ & + & + & + & + & + & - & + & + & + & + & + & + & + & + & + & - & + \\
\hline Maleate & - & - & 33 & - & - & - & - & - & - & - & - & - & - & - & - & - & - \\
\hline Fumarate $^{d}$ & + & + & 66 & + & + & - & + & + & + & + & + & + & + & + & + & - & + \\
\hline Glutarate & - & - & - & - & 66 & - & - & - & 50 & + & - & - & - & - & - & - & + \\
\hline Glycolate $^{d, e}$ & - & + & - & - & - & - & - & - & - & - & - & + & + & - & + & - & + \\
\hline DL-Lactate $^{d}$ & + & + & + & 50 & + & - & + & + & + & + & + & + & + & + & 60 & + & + \\
\hline DL-Glycerate ${ }^{d}$ & $75(+)$ & + & 66 & 50 & 66 & - & + & + & + & + & + & 70 & + & + & + & + & + \\
\hline DL-3-Hydroxybutyrate ${ }^{d, e}$ & $65(+)$ & + & 33 & - & 66 & - & 33 & + & + & + & + & 85 & 50 & + & + & 50 & + \\
\hline D-Malate ${ }^{d}$ & + & $50(+)$ & 66 & + & + & + & 66 & + & + & + & + & + & 50 & + & + & - & + \\
\hline L-Malate ${ }^{d}$ & + & + & + & + & + & - & + & + & + & + & + & + & + & + & + & - & + \\
\hline D-Tartrate ${ }^{d}$ & $15(-)$ & - & - & - & - & - & - & + & - & - & - & - & - & - & - & - & - \\
\hline L-Tartrate ${ }^{d}$ & - & - & - & - & - & - & + & - & - & + & - & - & - & - & - & - & - \\
\hline
\end{tabular}


TABLE 2-Continued

\begin{tabular}{|c|c|c|c|c|c|c|c|c|c|c|c|c|c|c|c|c|c|}
\hline \multirow[b]{2}{*}{ Substrate $^{a}$} & \multicolumn{17}{|c|}{ Utilization by: } \\
\hline & 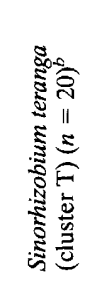 & 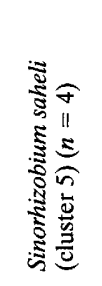 & 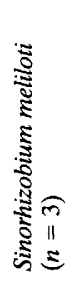 & 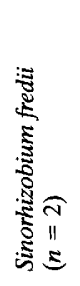 & 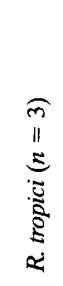 & 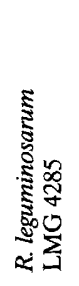 & 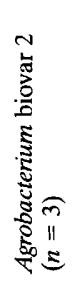 & 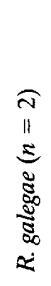 & 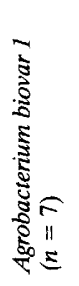 & 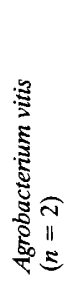 & 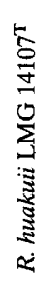 & 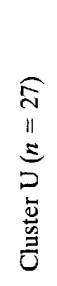 & 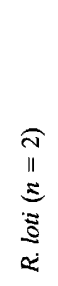 & 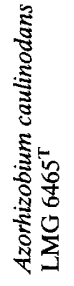 & 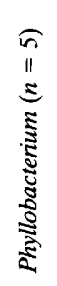 & 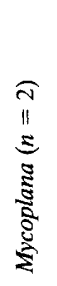 & 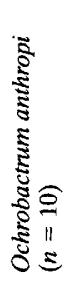 \\
\hline Meso-Tartrate ${ }^{d}$ & $15(-)$ & - & - & - & - & - & - & + & - & - & - & - & - & - & - & - & - \\
\hline Pyruvate $^{d}$ & + & + & + & 50 & 66 & - & + & + & 75 & + & + & + & + & + & + & + & 30 \\
\hline 2-Ketoglutarate ${ }^{d}$ & - & - & - & 50 & 66 & - & + & - & 50 & - & + & - & - & + & - & - & 70 \\
\hline Aconitate $^{d, e}$ & $85(-)$ & + & - & 50 & + & - & - & - & + & - & - & 11 & - & + & + & - & - \\
\hline Citrate $^{d}$ & - & - & - & - & + & - & + & - & - & + & - & 85 & - & + & + & - & + \\
\hline Phenylacetate $^{d}$ & - & - & - & - & - & - & - & - & - & - & - & - & - & - & - & + & - \\
\hline$m$-Hydroxybenzoate ${ }^{d}$ & - & - & - & - & - & - & - & + & - & - & - & - & - & - & - & - & - \\
\hline$p$-Hydroxybenzoate ${ }^{d, e}$ & $75(+)$ & + & - & - & + & + & + & + & 75 & + & - & - & - & + & + & - & 40 \\
\hline D-Mandelate ${ }^{d}$ & - & - & 33 & - & - & - & + & - & - & - & - & - & - & - & - & - & - \\
\hline L-Mandelate ${ }^{d}$ & - & - & - & - & - & - & + & - & - & - & - & - & - & - & - & - & - \\
\hline Glycine $^{d}$ & - & - & - & - & - & - & - & - & - & - & - & - & - & - & - & - & + \\
\hline $\mathrm{D}-(-)$-Alanine ${ }^{d}$ & - & - & - & - & 33 & - & - & - & 50 & - & - & - & - & - & 40 & - & + \\
\hline $\mathrm{L}-(-)$-Alanine & $80(+)$ & + & 66 & - & + & + & + & + & + & + & + & 81 & 50 & + & + & + & + \\
\hline L-Leucine ${ }^{d}$ & + & $75(w)$ & 66 & 50 & + & - & 66 & 50 & 25 & - & + & 85 & 50 & - & + & - & + \\
\hline L-Isoleucine ${ }^{d}$ & $50(+)$ & - & 66 & - & - & + & - & - & 25 & - & + & 55 & 50 & - & + & + & + \\
\hline L-Norleucine ${ }^{d}$ & - & - & - & - & - & - & - & - & 50 & - & - & - & - & - & - & - & + \\
\hline L-Valine $\mathrm{e}^{d, e}$ & $45(+)$ & + & 33 & - & - & - & - & - & 25 & - & - & 30 & - & - & 80 & 50 & + \\
\hline DL-Norvaline $^{d}$ & - & - & - & - & - & - & - & - & - & - & - & - & - & - & - & - & + \\
\hline $\mathrm{L}-S e r i n e^{d, e}$ & $35(-)$ & + & 33 & - & + & - & 66 & - & + & 50 & - & - & - & - & 80 & + & + \\
\hline L-Threonine $e^{d, e}$ & $70(+)$ & + & 66 & - & 66 & - & 33 & - & + & 50 & + & 33 & + & - & + & + & + \\
\hline L-Cysteine & - & - & - & - & - & - & - & - & 75 & - & - & - & - & - & - & - & 40 \\
\hline L-Phenylalanine $\mathrm{e}^{d}$ & - & $75(+)$ & - & 50 & + & - & - & - & - & - & - & 30 & 50 & - & - & + & - \\
\hline L-Tyrosine $^{d}$ & $15(-)$ & $75(-)$ & 66 & - & + & + & - & - & - & - & + & 89 & + & - & 20 & + & - \\
\hline L-Histidine ${ }^{d}$ & + & + & + & + & + & + & + & + & + & + & + & + & + & - & 20 & + & + \\
\hline L-Tryptophan & - & - & - & - & - & - & - & - & - & - & + & 63 & + & - & 60 & - & - \\
\hline Trigonelline $^{d, e}$ & - & $75(+)$ & + & 50 & - & - & + & - & 25 & + & - & 44 & 50 & - & 80 & - & - \\
\hline L-Aspartate ${ }^{d, e}$ & $65(+)$ & + & + & - & + & + & + & - & + & + & - & 30 & - & - & + & + & + \\
\hline L-Glutamate ${ }^{d}$ & + & + & + & + & + & + & 66 & - & + & 50 & + & + & + & + & + & + & + \\
\hline L-Ornithine ${ }^{d}$ & + & + & + & + & 66 & + & 66 & - & + & - & + & + & 50 & - & 20 & + & + \\
\hline L-Lysine $e^{d, e}$ & + & + & + & - & 66 & - & - & - & + & - & - & 55 & 50 & - & 60 & + & + \\
\hline L-Citrulline ${ }^{d, e}$ & - & + & - & 50 & - & - & 66 & - & + & - & - & - & - & - & - & - & + \\
\hline $\mathrm{L}-$ Arginine $^{d}$ & $80(+)$ & + & + & 50 & 66 & - & - & - & + & - & + & + & 50 & - & 20 & + & + \\
\hline L-Proline ${ }^{d}$ & + & + & + & 50 & + & + & 66 & + & + & + & - & + & + & - & + & + & + \\
\hline Betaine $^{d}$ & + & + & + & 50 & + & + & + & + & + & 50 & + & + & + & - & + & 50 & + \\
\hline Creatine $^{d}$ & - & - & - & - & - & - & - & - & - & - & - & - & - & - & - & + & - \\
\hline$\beta$-Alanine ${ }^{d, e}$ & - & $50(w)$ & + & - & - & - & - & - & 50 & - & - & 48 & 50 & - & 40 & + & + \\
\hline DL-3-Aminobutyrate ${ }^{d, e}$ & - & - & + & - & - & - & - & - & - & - & - & 18 & - & - & 20 & - & + \\
\hline DL-4-Aminobutyrate ${ }^{d}$ & + & $75(-)$ & + & + & 33 & + & - & - & 75 & + & - & + & + & - & + & + & + \\
\hline DL-5-Aminovalerate ${ }^{d}$ & $20(+)$ & $25(-)$ & 66 & - & - & - & - & - & 25 & - & - & 41 & + & - & 20 & + & + \\
\hline Sarcosine $^{d}$ & - & - & - & - & - & - & 33 & - & + & - & - & 74 & - & - & 20 & + & + \\
\hline Ethanolamine $^{d}$ & $65(+)$ & + & + & + & 66 & + & - & - & + & - & + & 22 & + & - & + & + & 80 \\
\hline Diaminobutane $^{d}$ & - & - & - & - & - & - & - & - & - & - & - & - & - & - & - & + & - \\
\hline Spermine & - & - & - & - & - & - & - & - & - & - & - & - & - & - & - & 50 & - \\
\hline Histamine & - & - & - & - & - & - & - & - & - & - & - & 67 & - & - & - & - & - \\
\hline Glucosamine $^{d}$ & + & + & + & + & + & + & 66 & + & 75 & + & + & + & 50 & - & 80 & 50 & 80 \\
\hline
\end{tabular}

${ }^{a}$ As determined by API 50 tests, all strains except Azorhizobium caulinodans LMG $6465^{\mathrm{T}}$ grew on L-arabinose, D-xylose, adonitol, D-galactose, D-glucose, D-fructose, and D-arabitol and did not grow on esculin, inulin, starch, glycogen, $n$-caproate, heptanoate, caprylate, pelargonate, adipate, pimelate, suberate, azelate, sebacate, levulinate, citraconate, itaconate, mesaconate, benzoate, $o$-hydroxybenzoate, phthalate, isophthalate, terephthalate, DL-2-aminobutyrate, L-methionine, D-tryptophan, DL-kynurenine, 2-aminobenzoate, 3-aminobenzoate, 4-aminobenzoate, urea, benzylamine, sarcosine, ethylamine, butylamine, amylamine, and tryptamine. Azorhizobium caulinodans LMG $6465^{\mathrm{T}}$ grew on suberate, azelate, and sebacate and did not grow on L-arabinose, D-xylose, adonitol, D-galactose, D-glucose, D-fructose, D-arabitol, esculin, inulin, starch, glycogen, $n$-caproate, heptanoate, caprylate, pelargonate, adipate, pimelate, levulinate, citraconate, itaconate, mesaconate, benzoate, $o$-hydroxybenzoate, phthalate, isophthalate, terephthalate, DL-2-aminobutyrate, L-methionine, D-tryptophan, DL-kynurenine, 2-aminobenzoate, 3-aminobenzoate, 4-aminobenzoate, urea, benzylamine, sarcosine, ethylamine, butylamine, amylamine, and tryptamine.

${ }^{b} n$ is the number of strains studied.

$c+$, all strains are positive; - , all strains are negative; $d$, less than $95 \%$ but more than 5\% of the strains are positive. The values are the percentages of positive strains. ${ }^{d}$ Carbon source that gave different results for different groups.

${ }^{e}$ Carbon source that could be used to distinguish Sinorhizobium saheli, Sinorhizobium teranga, Sinorhizobium fredii, and Sinorhizobium meliloti.

${ }^{f}$ The reactions in parentheses are the reactions of the type strains. w, weakly positive. 
Strain no.

Cluster name

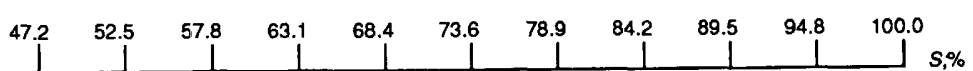

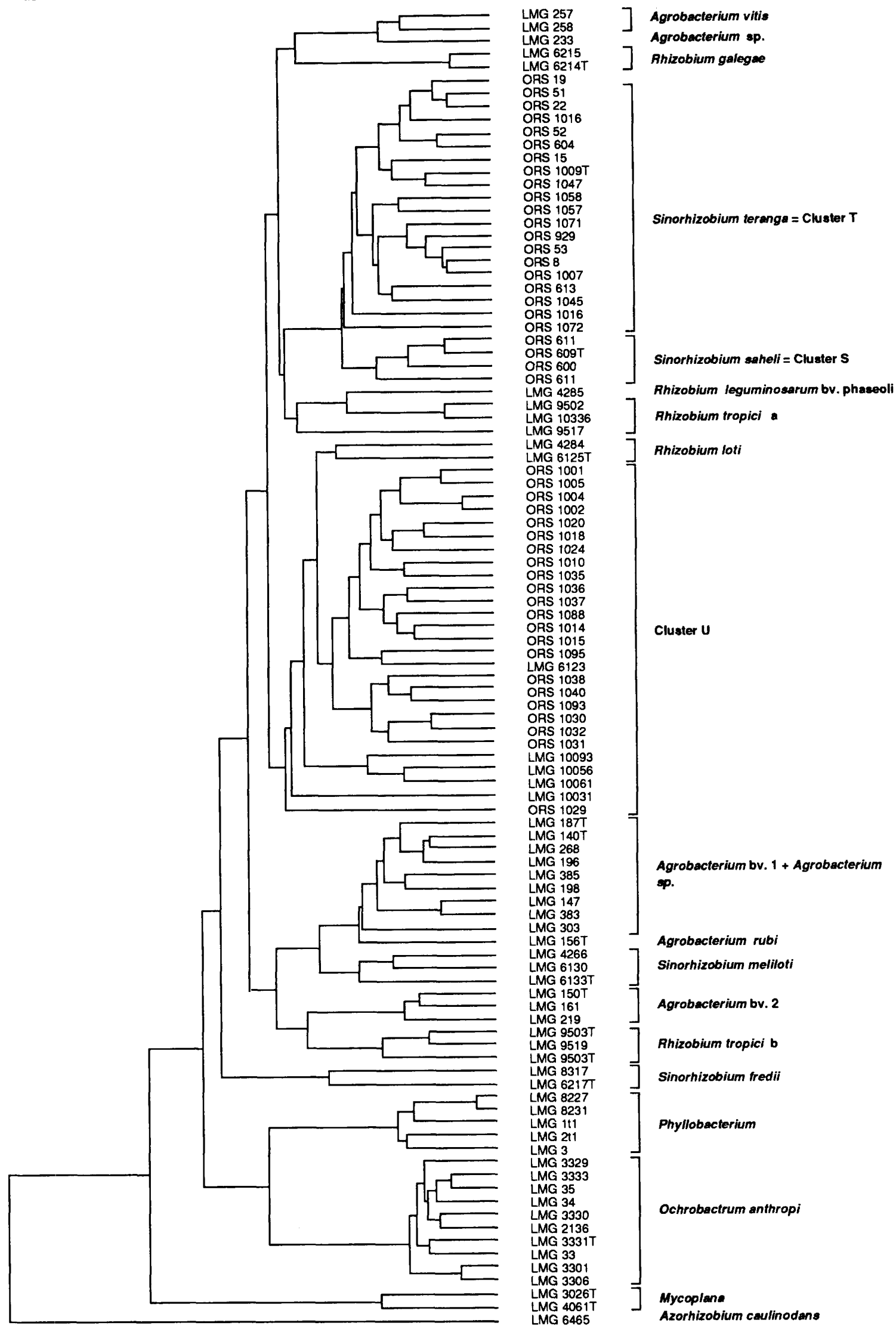

FIG. 3. Dendrogram obtained from an unweighted average pair group cluster analysis of Canberra metric similarity coefficients based on 147 auxanographic characteristics. 
TABLE 3. G $+\mathrm{C}$ contents and $T_{m(e)}$ values of DNA-rRNA hybrids determined by using labeled rRNAs from Sinorhizobium teranga ORS 22 , Sinorhizobium meliloti LMG 6130, and cluster U strain LMG 6123

\begin{tabular}{|c|c|c|c|c|c|}
\hline \multicolumn{2}{|l|}{ Source of DNA } & \multirow{2}{*}{$\begin{array}{l}G+C \text { content } \\
\quad(\mathrm{mol} \%)\end{array}$} & \multicolumn{3}{|c|}{$T_{m(e)}\left({ }^{\circ} \mathrm{C}\right)$ with $\left[{ }^{3} \mathrm{H}\right] \mathrm{rRNA}$ from: } \\
\hline Taxon & Strain & & $\begin{array}{l}\text { Sinorhizobium } \\
\text { teranga } \text { ORS } 22\end{array}$ & $\begin{array}{l}\text { Cluster U strain } \\
\text { LMG } 6123\end{array}$ & $\begin{array}{l}\text { Sinorhizobium meliloti } \\
\text { LMG } 6130\end{array}$ \\
\hline Sinorhizobium meliloti & LMG $6133^{\mathrm{T}}$ & & & 76.0 & $81.8^{a}$ \\
\hline R. leguminosarum biovar trifolii & LMG 6119 & $76.0^{a}$ & $79.7^{a}$ & & \\
\hline R. tropici & LMG $9503^{\mathrm{T}}$ & 59.7 & 77.3 & & 77.3 \\
\hline Sinorhizobium fredii & LMG 6219 & & & & 81.3 \\
\hline R. loti & LMG $6125^{\mathrm{T}}$ & & & $80.6^{a}$ & $76.4^{a}$ \\
\hline R. galegae & LMG $6214^{\mathrm{T}}$ & & & $74.5^{a}$ & 78.1 \\
\hline \multirow[t]{3}{*}{ Sinorhizobium teranga } & ORS 51 & 60.8 & & & $76.9(77.8)^{a}$ \\
\hline & ORS $1009^{\mathrm{T}}$ & 61.6 & 81.4 & & 77.1 \\
\hline & ORS 22 & & 81.3 & & $79.8^{a}$ \\
\hline \multirow[t]{2}{*}{ Sinorhizobium saheli } & ORS $609^{\mathrm{T}}$ & 65.7 & & & $79.7^{b}$ \\
\hline & ORS 611 & 65.7 & & & \\
\hline \multirow[t]{7}{*}{ Cluster U } & ORS $1001^{\mathrm{T}}$ & & & 78.3 & 73.0 \\
\hline & ORS 1002 & 62.6 & & 79.3 & \\
\hline & ORS 1024 & 63.1 & & & \\
\hline & ORS 1030 & 64.0 & & & \\
\hline & ORS 1037 & 63.3 & & & \\
\hline & LMG 6123 & 63.9 & & 81.2 & \\
\hline & LMG 10056 & 63.0 & & & \\
\hline Agrobacterium biovar 1 & LMG 196 & & & & $78.1^{a}$ \\
\hline Agrobacterium biovar 2 & LMG $150^{\mathrm{T}}$ & & & $75.1^{a}$ & $79.5^{a}$ \\
\hline
\end{tabular}

${ }^{a}$ Data from reference 19

$b$ The value in parentheses is from reference 14.

tests with API 50CH, API 50AO, and API 50AA galleries. We identified three groups among the Senegalese isolates, clusters $\mathrm{S}, \mathrm{T}$, and $\mathrm{U}$. In our genotypic studies we used DNA-rRNA hybridization and $16 \mathrm{~S}$ ribosomal DNA sequencing to determine the phylogenetic relationships and DNA-DNA hybridization to determine the species status of the groups. Consistent with the results of reports on tropical rhizobia isolated in Brazil (31) and Sudan (49), we found considerable heterogeneity in the SDS-PAGE protein profiles and phenotypic features of fast-growing rhizobia isolated in Senegal. Except for the members of cluster U (containing cluster FM2 [31]), the Senegalese isolates were electrophoretically distinct from the protein electrophoretic clusters described by Moreira et al. (31). A detailed auxanographic characterization of electrophoretic clusters $\mathrm{S}, \mathrm{T}$, and $\mathrm{U}$ was performed, and the results provided some distinguishing characteristics (Table 2). Generally, we obtained good correlations with previous carbon source utilization test results $(14,30)$, with the following exceptions. With L-phenylalanine, L-threonine, L-alanine, and L-tryptophan our results for $R$. tropici contradicted the results of MartinezRomero et al. (30); and for Rhizobium strains isolated from Sesbania spp. the data for $p$-hydroxybenzoate contradicted data in a previous report (14). For Azorhizobium spp. we observed more differences with previous results (14) since the organisms did not grow on malonate, maleate, adipate, pimelate, citraconate, L-aspartate, L-lysine, $m$-hydroxybenzoate, and glutarate, but did grow on DL-lactate and p-hydroxybenzoate. Also, in contrast to the results of Dreyfus et al. (14), we found that most of the cluster $\mathrm{T}$ and $\mathrm{S}$ strains could grow at $44^{\circ} \mathrm{C}$. The reasons for these discrepancies are probably that the previously described results were obtained by classical phenotypic techniques and that we used many more rhizobial isolates obtained from Acacia and Sesbania species but fewer R. fredii strains than were used in the previous studies. Only the type strain of $R$. huakuii was included in this study, and the results obtained for this organism agree well with the results described by Chen et al. (4), except that we observed growth on dulcitol and inositol.

On the basis of 16S rRNA gene sequencing and DNA-DNA hybridization results, clusters $\mathrm{S}$ and $\mathrm{T}$ were also shown to be genotypically distinct from each other and from the reference organisms examined. Strains belonging to these two clusters were shown to represent two branches of the $R$. meliloti-R. fredii subgroup (Fig. 4). Because internally both cluster $S$ and cluster $T$ exhibited high degrees of DNA binding and because no significant levels of DNA binding were detected between clusters $\mathrm{S}$ and $\mathrm{T}$ or between either cluster and $R$. meliloti or $R$. fredii (Table 4), we concluded that these clusters represent new genospecies. These taxa can be differentiated phenotypically (Table 2) from each other, from the other members of the $R$. meliloti-R. fredii subgroup, and from the members of the other subgroups of the Agrobacterium-Rhizobium group $(37,44,46)$, justifying species status for both groups. As explained previously (46), profound revision of the genus and species classification of the Agrobacterium-Rhizobium group is inevitable, because some Rhizobium species are phylogenetically more closely related to Agrobacterium subgroups than they are to other Rhizobium species. The results of polyphasic taxonomic studies which are now available (37; this study) should allow us to propose a general revision of the genera Rhizobium and Agrobacterium, as well as two new species for clusters $\mathrm{T}$ and $\mathrm{S}$. As discussed previously (46), revision of the classification of the Agrobacterium-Rhizobium group could include the description of a separate genus for the $R$. meliloti- $R$. fredii subgroup (including two new species for clusters $\mathrm{S}$ and $\mathrm{T}$ ); revision of the genus Agrobacterium so that it contains the biovar 1 strains, Agrobacterium vitis, Agrobacterium rubi, and [Rhizobium] galegae; and revision of the genus Rhizobium so that it contains $R$. leguminosarum (the type species), $R$. tropici, $R$. etli, and the [Agrobacterium] biovar 2 strains that constitute a separate new species. $R$. loti, $R$. huakuii, and our cluster $U$ constitute another lineage that also deserves separate genus status. However, 


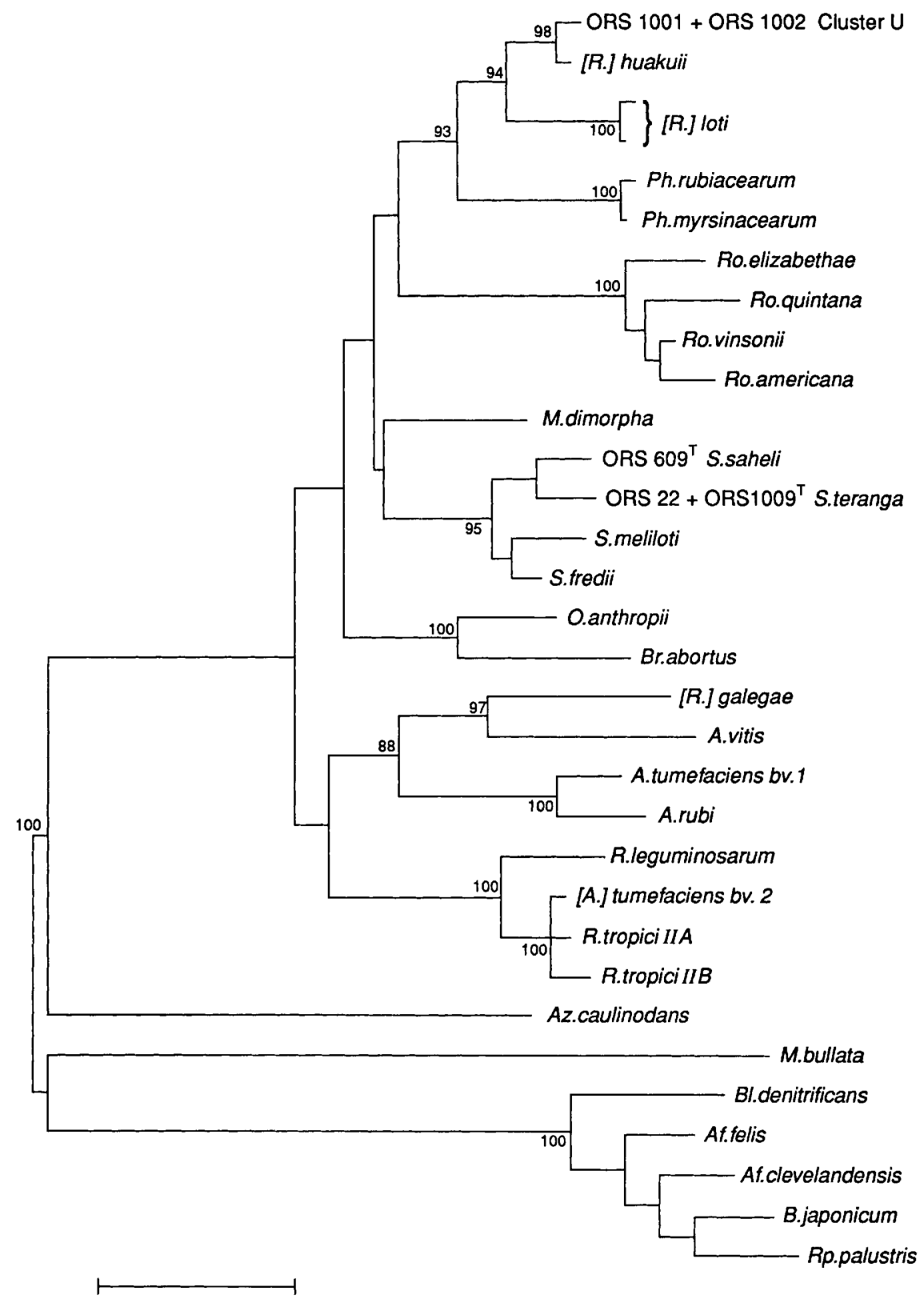

FIG. 4. Dendrogram obtained by the neighbor-joining method, showing the phylogenetic positions of Sinorhizobium saheli ORS $609^{\mathrm{T}}$, Sinorhizobium teranga ORS 22 and ORS $1009^{\mathrm{T}}$, and cluster U strains ORS 1001 and ORS 1002 within the alpha subclass of the Proteobacteria. Significant bootstrap probability values are indicated at the branching points. The bootstrap value for Sinorhizobium saheli and Sinorhizobium teranga was 67, and the bootstrap value for Sinorhizobium meliloti and Sinorhizobium fredii was 58. Bar $=2 \%$ nucleotide differences. Abbreviations: R., Rhizobium; Ph., Phyllobacterium; Ro., Rochalimaea; M., Mycoplana; S., Sinorhizobium; O., Ochrobactrum; Br., Brucella; A., Agrobacterium; Az., Azorhizobium; Bl., Blastobacter; Af., Afipia; B., Bradyrhizobium; Rp., Rhodopseudomonas.

because of nomenclatural controversy concerning the rearrangement proposed for the genus Agrobacterium $(2,37)$, it is not possible to start a thorough revision of the genera Rhizobium and Agrobacterium before it has been decided whether Agrobacterium tumefaciens or Agrobacterium radiobacter should be the type species of the revised genus Agrobacterium and whether the epithet "rhizogenes" will be retained for the species containing the biovar 2 strains. In the $R$. meliloti- $R$. fredii sublineage the nomenclatural changes are less complicated. On the basis of mainly phenotypic criteria, $R$. fredii has recently been designated the type species of a new genus,
Sinorhizobium (5). Although the proposal of Sinorhizobium by Chen et al. (5) has been questioned (18), the results of the present study demonstrate that $R$. fredii and $R$. meliloti, together with clusters $S$ and $T$, merit a distinct genus. Therefore, we formally propose to emend the genus Sinorhizobium and to reclassify $R$. meliloti as Sinorhizobium meliloti comb. nov. In addition, we propose two new species, Sinorhizobium saheli for cluster S strains and Sinorhizobium teranga for cluster T strains. The taxonomic position of $S$. xinjiangensis (5) remains to be determined. We realize the reference to China in the name Sinorhizobium does not apply to all the species proposed here, 
TABLE 4. Levels of DNA-DNA binding at $79.8^{\circ} \mathrm{C}$ between DNAs from Rhizobium, Sinorhizobium, and cluster U strains

\begin{tabular}{|c|c|c|c|c|c|c|c|c|c|c|c|c|c|c|c|}
\hline \multicolumn{2}{|l|}{ DNA from: } & \multicolumn{14}{|c|}{$\%$ Binding with DNA from: } \\
\hline Taxon & Strain & 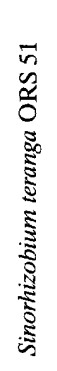 & 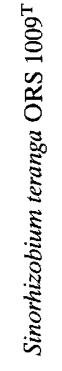 & 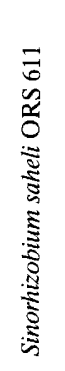 & 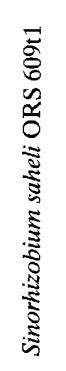 & 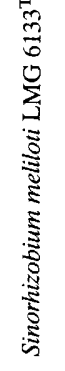 & 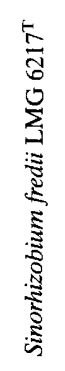 & 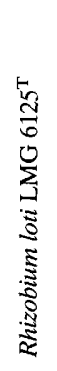 & 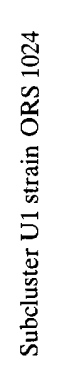 & 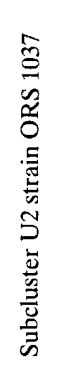 & 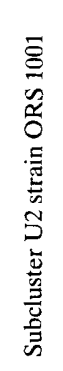 & 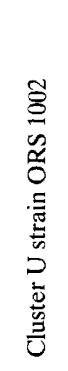 & 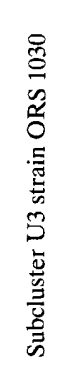 & 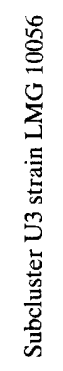 & 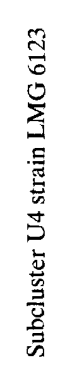 \\
\hline Sinorhizobium teranga & ORS 51 & 100 & & & & & & & & & & & & & \\
\hline Sinorhizobium teranga & ORS $1009^{\mathrm{T}}$ & 79 & 100 & & & & & & & & & & & & \\
\hline Sinorhizobium saheli & ORS 611 & 20 & & 100 & & & & & & & & & & & \\
\hline Sinorhizobium saheli & ORS $609 \mathrm{t} 1$ & & & 89 & 100 & & & & & & & & & & \\
\hline Sinorhizobium meliloti & LMG $6133^{\mathrm{T}}$ & 22 & & 23 & & 100 & & & & & & & & & \\
\hline Sinorhizobium fredii & LMG $6217^{\mathrm{T}}$ & 22 & & 26 & & 23 & 100 & & & & & & & & \\
\hline Rhizobium loti & LMG $6125^{\mathrm{T}}$ & & & & & & & 100 & & & & & & & \\
\hline Rhizobium sp. cluster U subcluster U1 & ORS 1024 & & & & & & & & 100 & & & & & & \\
\hline Rhizobium sp. cluster U subcluster U2 & ORS 1037 & & & & & & & & 83 & 100 & & & & & \\
\hline Rhizobium sp. cluster U subcluster U2 & ORS 1001 & & & & & & & 10 & & & 100 & & & & \\
\hline Rhizobium sp. cluster U & ORS 1002 & & & & & & & 13 & 77 & 88 & 80 & 100 & & & \\
\hline Rhizobium sp. cluster U subcluster U3 & ORS 1030 & & & & & & & & 37 & 38 & & 42 & 100 & & \\
\hline Rhizobium sp. cluster U subcluster U3 & LMG 10056 & & & & & & & & 28 & 29 & 40 & 47 & 32 & 100 & \\
\hline Rhizobium sp. cluster U subcluster U4 & LMG 6123 & & & & & & & 23 & 16 & 24 & & 14 & 33 & 25 & 100 \\
\hline
\end{tabular}

but we are bound by the rules of nomenclatural priority to use this name.

The taxonomic situation of cluster $\mathrm{U}$ is more complex because there is considerable genotypic heterogeneity among the strains belonging to this cluster. Preliminary DNA-DNA hybridization data indicated that there are at least two genomic species in cluster $\mathrm{U}$, one containing subclusters $\mathrm{U} 1, \mathrm{U} 2$, and U3 and strain ORS 1002 and one containing subcluster U4. Comparative 16S rRNA gene sequencing data revealed that cluster $U$ strains are phylogenetically closely related. These organisms belong to the $R$. loti-R. huakuii lineage, and $R$. lot is a close relative but is nevertheless distinct. At the present time we consider it unwise to assign species status to cluster $U$ because of the absence of distinguishing phenotypic traits. In addition, the 16S rRNA sequence data revealed that this taxon may be closely related to $R$. huakuii. Additional chromosomal DNA-DNA pairing studies performed with representative strains of cluster $\mathrm{U}$ and $R$. huakuii strains will be necessary to clarify the taxonomic relationships of these organisms.

Cluster U contains strains isolated from diverse plants (different Acacia species, Lotus divariaticus, different Leucaena species, and Chamaecrista ensiformis) in various countries (Senegal, Brazil, and New Zealand). In the study of Chen et al. (4) rather high levels of DNA binding between $R$. huakuii and isolates obtained from Leucaena leucocephala were found, and it is striking that four of the five Brazilian cluster $U$ isolates were also isolated from Leucaena species.

Emended description of Sinorhizobium (Chen, Yan and Li 1988). Rods that are 0.5 to 1 by 1.2 to $3 \mu \mathrm{m}$. Commonly pleiomorphic under adverse growth conditions. Cells usually contain poly- $\beta$-hydroxybutyrate granules which are refractile as determined by phase-contrast microscopy. Non-spore forming. Gram negative. Motile by means of one polar or subpolar flagellum or two to six peritrichous flagella. Fimbriae occur in a few strains. Aerobic, having a respiratory type of metabolism with oxygen as the terminal electron acceptor. Often able to grow well under oxygen tensions less than $1.0 \mathrm{~Pa}$. Optimum temperature, 25 to $33^{\circ} \mathrm{C}$. Optimum $\mathrm{pH}, 6$ to 7 . Colonies are circular, convex, semitranslucent, raised, and mucilaginous and usually are 2 to $4 \mathrm{~mm}$ in diameter within 3 to 5 days on yeast-mannitol-mineral salts agar. Pronounced turbidity develops after 2 to 3 days in agitated broth media. Chemoorganotrophic, utilizing a wide range of carbohydrates (but not cellulose and starch) and salts of organic acids as carbon sources (5) (Table 2). Cells produce an acid reaction in mineral salts media containing several carbohydrates. Peptone is poorly utilized. 3-Ketolactose is not produced from lactose. Growth on carbohydrate media is usually accompanied by copious extracellular polysaccharide slime production.

The organisms are typically able to invade the root hairs of temperate zone and tropical zone leguminous plants (family Leguminosae) and incite the production of root nodules, where the bacteria occur as intracellular symbionts. All strains exhibit host range activities ("host specificity"). The bacteria are present in root nodules as pleiomorphic forms (bacteriods) which are normally involved in fixing atmospheric nitrogen into a combined form (ammonia) that can be utilized by the host plant. The $\mathrm{G}+\mathrm{C}$ content of the DNA is 57 to $66 \mathrm{~mol} \%$ (as determined by the melting method). The type species is Sinorhizobium fredii.

At the molecular level the genus can be recognized by the sequence of the 16S rRNA genes.

Description of Sinorhizobium meliloti (Dangeard 1926) comb. nov. The description of the species is the description given by Jordan (20). In addition, this species can be differentiated from the other Sinorhizobium species by its auxanographic characteristics (5) (Table 2). At the molecular level it can be differentiated from other Sinorhizobium species by its gel electrophoretic protein profiles, by DNA-DNA hybridization data, and by the sequence of its 16S rRNA genes. 
Additional description of Sinorhizobium fredii (Scholla and Elkan 1984) (Chen, Yan and $\mathrm{Li}$ 1988). Descriptions of the species are given by Scholla and Elkan (38) and Chen et al. (5). In addition, this species can be differentiated from the other Sinorhizobium species by its auxanographic characteristics (5) (Table 2), and on the molecular level it can be differentiated by its protein electrophoretic profiles, by the results of DNADNA hybridization experiments, and by the sequence of its 16S rRNA genes.

Description of Sinorhizobium teranga sp. nov. Sinorhizobium teranga (te'ran.ga. local Wolof [a language of the West African Wolof people] n. teranga, hospitality; N. L. n. teranga, hospitality, referring to the fact that this species contains strains isolated from different host plants). Aerobic, gram-negative, non-spore-forming rods that are 0.5 to $0.7 \mu \mathrm{m}$ wide by 1.5 to 2 $\mu \mathrm{m}$ long. Motile by means of one or several polar or subpolar flagella in liquid medium. The cells grow on yeast mannitol medium at temperatures as high as $44^{\circ} \mathrm{C}$. Colonies of most strains on YMA are circular, cream colored, semitranslucent, and mucilaginous and sometimes spread over an entire plate within 2 to 4 days. Old colonies turn brown. The exceptions are strains ORS 22 and ORS 613, which produce nonmucilaginous colonies. In some strains nonmucilaginous mutants arise spontaneously during subculturing. A wide range of carbohydrates, organic acids, and amino acids are utilized as sole carbon sources for growth. Features that distinguish this species from other species and related genera are shown in Table 2. Grows on xylitol but not on L-citrulline and glycolate.

Strains can nodulate Sesbania and Acacia spp., Leucaena leucocephala, and $N$. oleracea.

At the molecular level this species can be differentiated by the results of DNA-rRNA hybridization experiments, by the SDS-PAGE patterns of proteins, by the results of total DNADNA hybridization experiments, and by the sequence of the $16 \mathrm{~S}$ ribosomal DNA.

The $\mathrm{G}+\mathrm{C}$ content is 60.8 to $61.6 \mathrm{~mol} \%$.

Well-studied strain ORS 1009 (= LMG 7854), which was isolated from Acacia laeta, is the type strain, and the characteristics of this strain are shown in Table 2. All Sinorhizobium teranga strains have been deposited in the Culture Collection of the Laboratorium voor Microbiologie, University of Ghent, Ghent, Belgium, and in the Culture Collection of the Laboratory of Soil Microbiology, ORSTOM, Dakar, Senegal.

Description of Sinorhizobium saheli sp. nov. Sinorhizobium saheli (sa'hel.i. N.L. gen. n. saheli, of the Sahel, the region in Africa where the organisms were isolated). Aerobic, gramnegative, non-spore-forming rods that are 0.5 to $0.7 \mu \mathrm{m}$ wide by 1.5 to $2 \mu \mathrm{m}$ long. Motile by means of one or several polar or subpolar flagella in liquid medium. Grows on YMA at temperatures up to $44^{\circ} \mathrm{C}$. On YMA the colonies are circular, white, semitranslucent, and convex. When there is confluent growth, the white centers of the original colonies have a marbled appearance.

A wide range of carbohydrates, organic acids, and amino acids are utilized as sole carbon sources for growth. Distinguishing features are shown in Table 2. Grows on L-citrulline and glycolate but not on xylitol.

Strains have been isolated from Sesbania species in the Sahel area and can nodulate different Sesbania species, Acacia seyal, Leucaena leucocephala, and $N$. oleracea.

At the molecular level this species can be differentiated from other Sinorhizobium species and related genera by the results of DNA-DNA hybridization and DNA-rRNA hybridization experiments, by the SDS-PAGE patterns of proteins, and by the sequence of the 16S rRNA genes.

The $\mathrm{G}+\mathrm{C}$ content of the DNA is 65 to $66 \mathrm{~mol} \%$.
Strain ORS 609 (= LMG 7837) is the type strain; the phenotypic characteristics of this organism are shown in Table 2. All Sinorhizobium saheli strains have been deposited in the Culture Collection of the Laboratorium voor Microbiologie, University of Ghent, Ghent, Belgium, and in the Culture Collection of the Laboratory of Soil Microbiology, ORSTOM, Dakar, Senegal.

\section{ACKNOWLEDGMENTS}

We thank N. Dupuy for helpful discussions and S. Badji and I. Ndoye for kindly providing Rhizobium strains. We thank D. Monget and bioMérieux, Montalieu-Vercieu, France, for supplying API galleries.

This work was supported by the Commission of the European Communities (STD3 Programme contract TS2 0169-F; BRIDGE Programme contracts BIOT-CT91-0263 and BIOT-CT91-0294). M.G. and K.K. are indebted to the Nationaal Fonds voor Geneeskundig Onderzoek, Belgium, for research and personnel grants. A.W. is indebted to the Commission of the European Communities for a sectoral grant in the BRIDGE Programme.

\section{REFERENCES}

1. Badji, S. Unpublished data.

2. Bouzar, H. 1994. Request for a Judicial Opinion concerning the type species of Agrobacterium. Int. J. Syst. Bacteriol. 44:373-374.

3. Brosius, J., M. L. Palmer, P. J. Kennedy, and H. F. Noller. 1978. Complete nucleotide sequence of a $16 \mathrm{~S}$ ribosomal RNA gene from Escherichia coli. Proc. Natl. Acad. Sci. USA 75:4801-4805.

4. Chen, W. X., G. S. Li, Y. L. Qi, E. T. Wang, H. L. Yuan, and J. L. Li. 1991. Rhizobium huakuii sp. nov. isolated from the root nodules of Astralagus sinicus. Int. J. Syst. Bacteriol. 41:275-280.

5. Chen, W. X., G. H. Yan, and J. L. Li. 1988. Numerical taxonomic study of fast-growing soybean rhizobia and a proposal that Rhizobium fredii be assigned to Sinorhizobium gen. nov. Int. J. Syst. Bacteriol. 38:392-397.

6. Crow, V. L., B. D. H. Jarvis, and R. M. Greenwood. 1981. Deoxyribonucleic acid homologies among acid-producing strains of Rhizobium. Int. J. Syst. Bacteriol. 31:152-172.

7. Dangeard, P. A. 1926. Recherches sur les tubercles radicaux des Légumineuses. Botaniste 13:1-275.

8. De Ley, J. 1970. Reexamination of the association between melting point, buoyant density, and chemical base composition of deoxyribonucleic acid. J. Bacteriol. 101:737-754.

9. De Ley, J. 1991. The proteobacteria: ribosomal RNA cistron similarities and bacterial taxonomy, p. 2109-2140. In A. Balows, H. G. Trüper, M. Dworkin, W. Harder, and K. H. Schleifer (ed.), The prokaryotes, 2nd. ed. Springer-Verlag, New York.

10. De Ley, J., H. Cattoir, and A. Reynaerts. 1970. The quantitative measurement of DNA hybridization from renaturation rates. Eur. J. Biochem. 12:133-142.

11. De Ley, J., and J. De Smedt. 1975. Improvements of the membrane filter method for DNA:rRNA hybridization. Antonie van Leeuwenhoek J, Microbiol. Serol. 41:287-307.

12. De Ley, J., and J. Van Muylem. 1963. Some applications of deoxyribonucleic acid base composition in bacterial taxonomy. Antonie van Leeuwenhoek J. Microbiol. Serol. 29:344-358.

13. Devereux, J., P. Haeberli, and O. Smithies. 1984. A comprehensive set of sequence analysis programs for the VAX. Nucleic Acids Res. 12:387-395.

14. Dreyfus, B., J. L. Garcia, and M. Gillis. 1988. Characterization of Azorhizobium caulinodans gen. nov., sp. nov., a stem-nodulating nitrogen-fixing bacterium isolated from Sesbania rostrata. Int. J. Syst. Bacteriol. 38:89-98.

15. Dreyfus, B. L., and Y. Dommergues. 1981. Nodulation of Acacia species by fast- and slow-growing tropical strains of Rhizobium. Appl. Environ. Microbiol. 41:97-99.

16. Felsenstein, J. 1982. Numerical methods for inferring evolutionary trees. Q. Rev. Biol. 57:379-404.

17. Graham, P. H., M. J. Sadowsky, H. H. Keyser, Y. M. Barnet, R. S. Bradley, J. E. Cooper, J. De Ley, B. D. W. Jarvis, E. B. Roslycky, B. W. Strijdom, and J. P. W. Young. 1991. Proposed minimal 
standards for the description of new genera and species of rootand stem-nodulating bacteria. Int. J. Syst. Bacteriol. 41:582-587.

18. Jarvis, B. D. W., H. L. Downer, and J. P. W. Young. 1992. Phylogeny of fast-growing soybean-nodulating rhizobia supports synonymy of Sinorhizobium and Rhizobium and assignment to Rhizobium fredii. Int. J. Syst. Bacteriol. 42:93-96.

19. Jarvis, B. D. W., M. Gillis, and J. De Ley. 1986. Intra- and intergeneric similarities between the ribosomal ribonucleic acid cistrons of Rhizobium and Bradyrhizobium species and some related bacteria. Int. J. Syst. Bacteriol. 36:129-138.

20. Jordan, D. C. 1984. Rhizobiaceae Conn $1938,321^{\mathrm{AL}}$, p. $234-256$. In N. R. Krieg and J. G. Holt (ed.), Bergey's manual of systematic bacteriology, vol. 1. The Williams \& Wilkins Co., Baltimore.

21. Kersters, K., and J. De Ley. 1984. Genus III. Agrobacterium Conn 1942, p. 244-254. In N. R. Krieg and J. G. Holt (ed.), Bergey's manual of systematic bacteriology, vol. 1. The Williams \& Wilkins Co., Baltimore.

22. Kersters, K., K. H. Hinz, A. Hertle, P. Segers, A. Lievens, O. Siegmann, and J. De Ley. 1984. Bordetella avium sp. nov., isolated from the respiratory tracts of turkeys and other birds. Int. J. Syst. Bacteriol. 34:56-70.

23. Kiredjian, M., B. Holmes, K. Kersters, J. Guilvout, and J. De Ley. 1986. Alcaligenes piechaudii, a new species from human clinical specimens and the environment. Int. J. Syst. Bacteriol. 36:282-287.

24. Laemmli, U. K. 1970. Cleavage of structural proteins during the assembly of the head of bacteriophage T4. Nature (London) 227:680-685.

25. Lickfield, K. G. 1976. Transmission electron microscopy of bacteria. Methods Microbiol. 9:130.

26. Lindström, K. 1989. Rhizobium galegae, a new species of legume root nodule bacteria. Int. J. Syst. Bacteriol. 39:365-367.

27. Lortet, J. Unpublished data.

28. Marmur, J. 1961. A procedure for the isolation of deoxyribonucleic acid from microorganisms. J. Mol. Biol. 3:208-218.

29. Marmur, J., and P. Doty. 1962. Determination of the base composition of deoxyribonucleic acid from its thermal denaturation temperature. J. Mol. Biol. 5:109-118.

30. Martinez-Romero, E., L. Segovia, F. M. Mercante, A. A. Franco, P. Graham, and M. A. Pardo. 1991. Rhizobium tropici, a novel species nodulating Phaseolus vulgaris $\mathrm{L}$. beans and Leucaena sp. trees. Int. J. Syst. Bacteriol. 41:417-426.

31. Moreira, F., M. Gillis, B. Pot, K. Kersters, and A. A. Franco. 1993. Characterization of rhizobia isolated from different divergence groups of tropical Leguminosae by comparative polyacrylamide gel electrophoresis of their total proteins. Syst. Appl. Microbiol. 16: 135-146.

32. Ndoye, I. Unpublished data.

33. Pot, B., M. Gillis, B. Hoste, A. Van De Velde, F. Bekaert, K. Kersters, and J. De Ley. 1989. Intra- and intergeneric relationships of the genus Oceanospirillum. Int. J. Syst. Bacteriol. 39:23-34.

34. Pot, B., P. Vandamme, and K. Kersters. 1994. Analysis of electrophoretic whole organism protein fingerprints, p. 493-521. In M. Goodfellow and T. O'Donnell (ed.), Chemical methods in prokaryotic systematics. John Wiley \& Sons, Chichester, United
Kingdom

35. Rinaudo, G., M. P. Fernandez, A. Effosse, B. Picard, and R. Bardin. 1993. Enzyme polymorphism of Azorhizobium strains and other stem and root-nodulating bacteria isolated from Sesbania rostrata. Res. Microbiol. 154:55-67.

36. Rinaudo, G., S. Orenga, M. Fernandez, H. Meugnier, and R. Bardin. 1991. DNA homologies among members of the genus Azorhizobium and other stem- and root-nodulating bacteria isolated from the tropical legume Sesbania rostrata. Int. J. Syst. Bacteriol. 41:114-120.

37. Sawada, H., H. Ieki, H. Oyaizu, and S. Matsumoto. 1993. Proposal for rejection of Agrobacterium tumefaciens and revised descriptions for the genus Agrobacterium and for Agrobacterium radiobacter and Agrobacterium rhizogenes. Int. J. Syst. Bacteriol. 43:694-702.

38. Scholla, M. H., and G. H. Elkan. 1984. Rhizobium fredii sp. nov., a fast-growing species that effectively nodulates soybeans. Int. J. Syst. Bacteriol. 34:484-486.

39. Segovia, L., J. P. W. Young, and E. Martinez-Romero. 1993. Reclassification of American Rhizobium leguminosarum biovar phaseoli type I strains as Rhizobium etli sp. nov. Int. J. Syst. Bacteriol. 43:374-377.

40. Sneath, P. H. A., and R. R. Sokal. 1973. Numerical taxonomy. The principles and practice of numerical classification. W. H. Freeman and Co., San Francisco.

41. Vauterin, L., and P. Vauterin. 1992. Computer-aided objective comparison of electrophoresis patterns for grouping and identification of microorganisms. Eur. Microbiol. 1:37-41.

42. Vincent, J. M. 1970. A manual for the practical study of rootnodule bacteria. International Biological Programme Handbook no. 15, p. 73-97. Blackwell Scientific Publications, Ltd., Oxford.

43. Willems, A., and M. D. Collins. 1992. Evidence for a close genealogical relationship between Afipia, the causal organism of cat scratch disease, Bradyrhizobium japonicum and Blastobacter denitrificans. FEMS Microbiol. Lett. 96:241-246.

44. Willems, A., and M. D. Collins. 1993. Phylogenetic analysis of rhizobia and agrobacteria based on $16 \mathrm{~S}$ ribosomal DNA sequences. Int. J. Syst. Bacteriol. 43:305-313.

45. Wishart, D. 1978. Clustan users manual, 3rd ed. Program Library Unit, Edinburgh University, Edinburgh, Scotland.

46. Yanagi, M., and K. Yamasoto. 1993. Phylogenetic analysis of the family Rhizobiaceae and related bacteria by sequencing of $16 \mathrm{~S}$ rRNA gene using PCR and DNA sequencer. FEMS Microbiol. Lett. 107:115-120.

47. Young, J. P. W. 1991. Phylogenetic classification of nitrogen-fixing organisms, p. 43-86. In G. Stacey, R. H. Burris, and H. J. Evans (ed.), Biological nitrogen fixation. Chapman \& Hall, New York.

48. Young, J. P. W., H. L. Downer, and B. D. Eardly. 1991. Phylogeny of the phototrophic Rhizobium strain BTAi1 by polymerase chain reaction-based sequencing of a $16 \mathrm{~S}$ rRNA gene segment. J. Bacteriol. 173:2271-2277.

49. Zhang, X., R. Harper, M. Karsisto, and K. Lindström. 1991. Diversity of Rhizobium bacteria isolated from root nodules of leguminous trees. Int. J. Syst. Bacteriol. 41:104-113. 